University of Tennessee Health Science Center UTHSC Digital Commons

$12-2015$

\title{
Reprogramming to Pluripotency Using Small Molecule Compounds
}

\author{
Brittany E. Greenberg \\ University of Tennessee Health Science Center
}

Follow this and additional works at: https://dc.uthsc.edu/dissertations

Part of the Medical Molecular Biology Commons

\section{Recommended Citation}

Greenberg, Brittany E. , "Reprogramming to Pluripotency Using Small Molecule Compounds" (2015). Theses and Dissertations (ETD). Paper 97. http://dx.doi.org/10.21007/etd.cghs.2015.0117. 


\title{
Reprogramming to Pluripotency Using Small Molecule Compounds
}

\begin{abstract}
The generation of induced pluripotent stem cells (iPSCs) through the use of small molecule compounds has evolved as a potential cellular reprogramming strategy. Individually, specific small molecule compounds have previously been shown to replace reprogramming transcription factors or enhance the efficiency of cellular reprogramming. More recently, a combination of small molecule compounds can replace all of the reprogramming factors. In this review, we describe in detail the generation of chemically induced pluripotent stem cells using small molecule inhibitors and activators that target either downstream protein kinases or modify chromatin structure to promote somatic cell reprogramming. In addition, epigenetic modulating small molecule compounds that enhance cellular reprogramming and functionally replace some reprogramming factors are discussed.
\end{abstract}

\section{Document Type}

Thesis

Degree Name

Master of Science (MS)

Program

Biomedical Sciences

Research Advisor

R. Kiplin Guy, PhD

Keywords

cell reprogramming, cell signaling, epigenetic modification, induced pluripotent stem cell (iPSC), small molecule compound

\section{Subject Categories}

Medical Molecular Biology | Medical Sciences | Medicine and Health Sciences 


\title{
Reprogramming to Pluripotency Using Small Molecule Compounds
}

\author{
A Thesis \\ Presented for \\ The Graduate Studies Council \\ The University of Tennessee \\ Health Science Center
}

In Partial Fulfillment

Of the Requirements for the Degree

Master of Science

From The University of Tennessee

By

Brittany E. Greenberg

December 2015 
Copyright $(\mathcal{C} 2015$ by Brittany E. Greenberg. All rights reserved. 


\section{DEDICATION}

This is dedicated to St. Jude Children's Research Hospital. 


\section{ACKNOWLEDGEMENTS}

I would like to express my gratitude to Dr. R. Kiplin Guy and Dr. Mark E. Hatley for their mentorship and insight over the past three years. Thank you both for your continuous guidance and motivation throughout this process. In addition, I would like to acknowledge Dr. Gerard P. Zambetti for his insight and encouragement, and for serving on my thesis committee.

I am also sincerely grateful to my family and friends for their invaluable support. 


\begin{abstract}
The generation of induced pluripotent stem cells (iPSCs) through the use of small molecule compounds has evolved as a potential cellular reprogramming strategy. Individually, specific small molecule compounds have previously been shown to replace reprogramming transcription factors or enhance the efficiency of cellular reprogramming. More recently, a combination of small molecule compounds can replace all of the reprogramming factors. In this review, we describe in detail the generation of chemically induced pluripotent stem cells using small molecule inhibitors and activators that target either downstream protein kinases or modify chromatin structure to promote somatic cell reprogramming. In addition, epigenetic modulating small molecule compounds that enhance cellular reprogramming and functionally replace some reprogramming factors are discussed.
\end{abstract}




\section{TABLE OF CONTENTS}

CHAPTER 1. INTRODUCTION ..................................................................................

CHAPTER 2. SMALL MOLECULE COMPOUNDS THAT MODULATE CELLULAR PATHWAYS TO PROMOTE IPSC PRODUCTION ............................7

FGF/MAPK/ERK Signaling Pathway ...............................................................

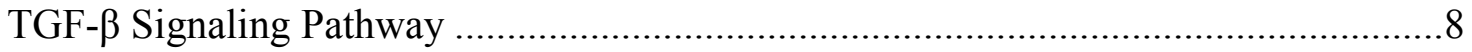

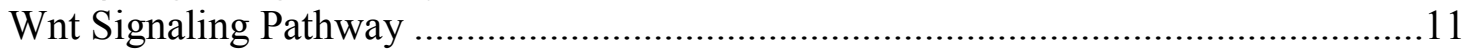

Sonic Hedgehog Homolog (SHH) Signaling Pathway ........................................... 13

cAMP Signaling Pathway ................................................................................... 15

Additional Signaling Pathway Small Molecule Modulators That Promote IPSC

Production

CHAPTER 3. SMALL MOLECULE EPIGENETIC MODULATING COMPOUNDS THAT FACILIATE REPROGRAMMING EFFICIENCY

DURING IPSC PRODUCTION .............................................................................18

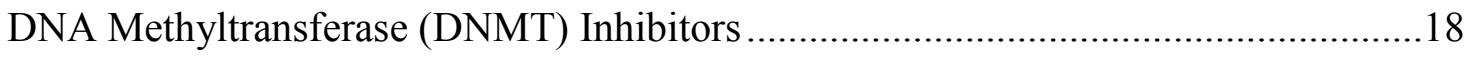

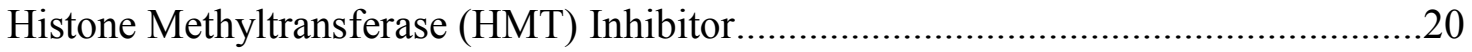

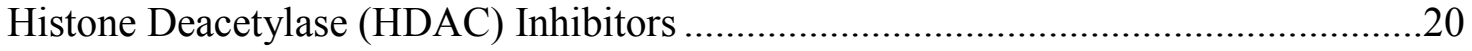

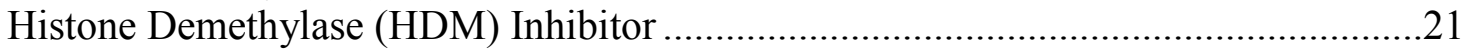

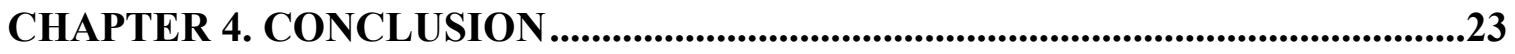

LIST OF REFERENCES .......................................................................................24

VITA 


\section{LIST OF TABLES}

Table 1-1. Small molecules promoting somatic cell reprogramming ............................3 


\section{LIST OF FIGURES}

Figure 2-1. FGF/MAPK/ERK Signaling Pathway ...................................................

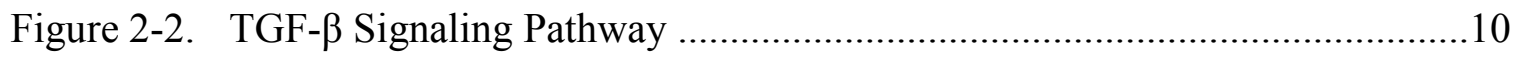

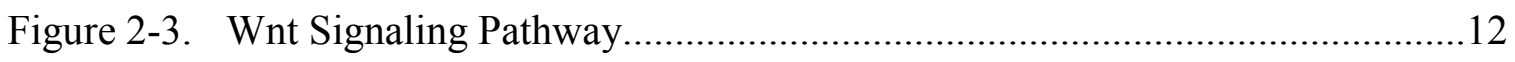

Figure 2-4. Sonic Hedgehog Homolog (SHH) Signaling Pathway ............................... 14

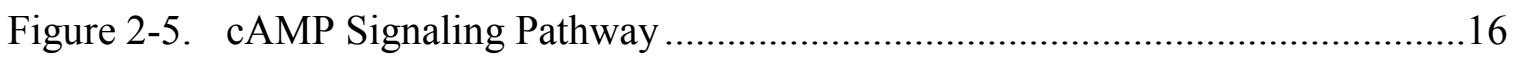

Figure 3-1. Small Molecule Epigenetic Compounds...................................................19 


\section{CHAPTER 1. INTRODUCTION}

Since Yamanaka and colleagues reported the generation of induced pluripotent stem cells (iPSCs) from mouse embryonic fibroblasts (MEFs) there has been a growing amount of research in stem cells particularly concerning cellular reprogramming to generate them and control their cell fate. The virus-mediated overexpression of four specific transcription factors (Oct3/4, Sox2, Klf4, and c-Myc (OSKM)) reprograms mouse embryonic fibroblasts into pluripotent cells that share similar characteristics with embryonic stem cells (ESCs) including gene expression, epigenetic characteristics, and developmental potential (Takahashi and Yamanaka 2006, Takahashi, Tanabe et al. 2007). Subsequently, human adult fibroblasts were reprogrammed into iPSCs by overexpressing the same four factors, or a combination of other factors including Nanog and Lin28 (Yu, Vodyanik et al. 2007). Human iPSCs (hiPSCs) derived from fibroblasts share characteristics with human ESCs (hESCs), including the ability to differentiate into cell types of all three germ layers. This is thought to occur through the restoration of the transcriptional circuitry and epigenetic factors involved in pluripotency. iPSCs also closely resemble PSCs in their biological properties and epigenetic characteristics (Jaenisch and Young 2008, Yamanaka and Blau 2010, Yamanaka 2012).

Interestingly, the four specific transcription factors inducing cellular reprogramming to pluripotency have been shown to each have a distinct role. The molecular events leading to the induction of pluripotency has recently been reviewed (Kulcenty, Wroblewska et al. 2015). Exogenous Oct3/4 and Sox 2 are required for mature iPSC production, while exogenous Klf4 and c-Myc enhance reprogramming efficiency (Takahashi, Tanabe et al. 2007). c-Myc targets have been shown to regulate cellular proliferation, metabolism, and biosynthetic pathways, while Oct4, Klf4 and Sox 2 targets have been shown to regulate the transcriptional and developmental regulators of pluripotency (Chen, Xu et al. 2008, Kim, Chu et al. 2008, Sridharan, Tchieu et al. 2009, Kim, Woo et al. 2010). During the initial phase of reprogramming, c-Myc activates pluripotency markers after induction of OSKM into target cells (Polo, Anderssen et al. 2012). c-Myc couples with histone acetyltransferase complexes and promotes histone acetylation, leading to the binding of exogenous Oct3/4 and Sox 2 to DNA (Soufi, Donahue et al. 2012). The transcription factor Klf4 has opposing roles. During the initial phase of reprogramming, Klf4 inhibits the expression of reprogramming genes, yet during the later phase of reprogramming Klf4 activates expression of Nanog in addition to other stem cell genes by repressing p53 (Lin, Chao et al. 2005, Rowland, Bernards et al. 2005). Sox 2 is expressed during the entire reprogramming process, while Oct $3 / 4$ activation during the later stages is essential to generate fully reprogrammed, mature iPSCs (Chen, Vega et al. 2008, Samavarchi-Tehrani, Golipour et al. 2010, Polo, Anderssen et al. 2012). More specifically, Oct3/4 recruits chromatin-remodeling complexes to regulatory regions, (Singhal, Graumann et al. 2010) in addition to binding to heterochromatin (Soufi, Donahue et al. 2012).

Although iPSCs have been key investigational tools in stem cell research and are

emerging as a focus in drug discovery, clinical application has been limited by the use of 
viral delivery systems for the transcription factors and the introduction of oncogenic c-Myc, both of which contribute to iPSC tumorigenicity. Most hiPSCs are made using retroviruses or lentiviruses, which have the capacity to integrate the reprogramming transcription factors into host genomes, increasing the potential for tumor formation. Viral integration may be deleterious because once integrated, the provirus is replicated, along with the host-cell DNA, and genetically incorporated into the host genome (Okita, Ichisaka et al. 2007, Zhao, Zhang et al. 2011, Polo, Anderssen et al. 2012). In addition, viral integration may affect the differentiation of iPSCs. Direct delivery and transient expression of the reprogramming factors using adenovirus vectors or plasmids are two methods that have been shown to avoid genomic alterations of iPSCs (Okita, Nakagawa et al. 2008, Stadtfeld, Nagaya et al. 2008, Okita, Matsumura et al. 2011). RNAs have also been utilized to generate iPSCs while reducing the risk of genomic integration of oncogenes, and increasing reprogramming efficiency (Warren, Manos et al. 2010, Anokye-Danso, Trivedi et al. 2011, Li, Yang et al. 2011, Subramanyam, Lamouille et al. 2011, Yang, Li et al. 2011, Bao, Zhu et al. 2013, Rabinovich and Weissman 2013, Wang and $\mathrm{Na} 2013$ ). In addition, protein-induced pluripotent stem cells have been reported (Kim, Kim et al. 2009, Zhou, Wu et al. 2009) and previously reviewed, (Higuchi, Ling et al. 2015) and whole cell extracts have also been used to achieve complete reprogramming into iPSCs without the expression of transgenes (Cho, Lee et al. 2010). However, these transient expression methods are extremely inefficient. The efficiency of protein-iPSC generation, for example, is approximately $0.001 \%$, further suggesting the need for a better reprogramming method (Higuchi, Ling et al. 2015).

Small molecules that target a specific signaling pathway, epigenetic process or other cellular processes have the ability to reprogram somatic cells into iPSCs without the use of heterologous genetic material or proteins (Huangfu, Maehr et al. 2008, Feng, Ng et al. 2009, Anastasia, Pelissero et al. 2010, Firestone and Chen 2010, Li and Ding 2010, Lukaszewicz, McMillan et al. 2010, Zhang 2010, Zhu, Li et al. 2010, Zhu, Wei et al. 2011, Li, Jiang et al. 2012, Gross, Sgodda et al. 2013, Hou, Li et al. 2013, Lu, Kong et al. 2013, Wu, Pandian et al. 2013, Xie, Cao et al. 2014). Substantial progress has been made in discovering small molecule compounds that maintain pluripotency by functionally replacing one of the distinct reprogramming transcription factors. These molecules can also enhance the efficiency of reprogramming and accelerate the reprogramming process. Small molecule compounds can directly regulate the expression of pluripotent transcription factor genes, resulting in the reprogramming of somatic cells into iPSCs (Huangfu, Osafune et al. 2008, Shi, Desponts et al. 2008, Ichida, Blanchard et al. 2009, Li, Zhou et al. 2009, Lin, Ambasudhan et al. 2009, Lyssiotis, Foreman et al. 2009, Maherali and Hochedlinger 2009, Esteban, Wang et al. 2010) (Table 1-1).

The first study reporting to reprogram mouse somatic cells to pluripotency without the use of genetic manipulation used a combination of seven small molecule compounds (Hou, Li et al. 2013). Ultimately, one of the goals in cellular reprogramming to hiPSCs is to have small molecules substitute for all four distinct transcription factors. In this review, we highlight the major classes of small molecule modulators of key signaling pathways and small molecule epigenetic modulators, used to date, to enhance the efficiency of cellular reprogramming, in addition to their prospective opportunities. 
Table 1-1. Small molecules promoting somatic cell reprogramming

\begin{tabular}{|c|c|c|c|c|}
\hline Small Molecules & Function & Effects on Reprogramming & $\begin{array}{c}\text { Host } \\
\text { Animal }\end{array}$ & Reference \\
\hline \multicolumn{5}{|l|}{ TGF $\beta$ receptor inhibitors } \\
\hline $\begin{array}{l}616452(\mathrm{E}-616452 \\
\text { RepSox })\end{array}$ & $\begin{array}{l}\text { TGF- } \beta \text { inhibitor (ALK } \\
\text { inhibitor II) }\end{array}$ & can replace Sox 2 & $\begin{array}{l}\text { mouse, } \\
\text { human }\end{array}$ & $\begin{array}{l}\text { Attisano \& Wrana 2002; } \\
\text { Ichida, Blanchard } 2009\end{array}$ \\
\hline A83-01 & TGF- $\beta$ inhibitor & reprogramming enhancer & $\begin{array}{l}\text { mouse, } \\
\text { human }\end{array}$ & $\begin{array}{l}\text { Zhu, Li 2010; Yuan, } \\
\text { Wan } 2011\end{array}$ \\
\hline LY-364947 & TGF- $\beta$ inhibitor & can replace Sox 2 & mouse & $\begin{array}{l}\text { Ichida, Blanchard 2009; } \\
\text { Staerk, Lyssiotis } 2011\end{array}$ \\
\hline SB431542 & TGF- $\beta$ inhibitor & reprogramming enhancer & $\begin{array}{l}\text { mouse, } \\
\text { human }\end{array}$ & Li, Zhou 2009 \\
\hline \multicolumn{5}{|l|}{ 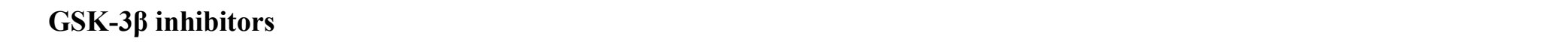 } \\
\hline CHIR99021 (CHIR) & $\begin{array}{l}\text { GSK-3 } \beta \text { inhibitor } \& \text { Wnt } \\
\text { signaling pathway activator }\end{array}$ & can replace Sox2 & $\begin{array}{l}\text { mouse, } \\
\text { human }\end{array}$ & $\begin{array}{l}\text { Li, Zhou 2009;Li, Zhang } \\
2011\end{array}$ \\
\hline Kenpaullone & GSK-3/CDKs inhibitor & can replace Klf4 & mouse & Lyssiotis, Foreman 2009 \\
\hline Compound B6 & GSK-3 $\beta$ inhibitor & reprogramming enhancer & mouse & Li, Rana 2012 \\
\hline Lithium Chloride (LiCl) & $\begin{array}{l}\text { GSK-3 } \beta \text { inhibitor, LSD1 } \\
\text { inhibitor }\end{array}$ & reprogramming enhancer & $\begin{array}{l}\text { mouse, } \\
\text { human }\end{array}$ & Wang, Xu 2011 \\
\hline \multicolumn{5}{|l|}{ MEK inhibitor } \\
\hline PD0325901 (PD) & MEK inhibitor & reprogramming enhancer & $\begin{array}{l}\text { mouse, } \\
\text { human }\end{array}$ & Shi, Do 2008 \\
\hline
\end{tabular}




\section{Table 1-1. Continued}

\begin{tabular}{|c|c|c|c|c|}
\hline Small Molecules & Function & Effects on Reprogramming & $\begin{array}{c}\text { Host } \\
\text { Animal }\end{array}$ & Reference \\
\hline \multicolumn{5}{|l|}{ cAMP agonists } \\
\hline Forskolin (FSK) & $\begin{array}{l}\text { Adenylyl cyclase agonist, } \\
\text { causes an increase in cAMP } \\
\text { levels }\end{array}$ & $\begin{array}{l}\text { can replace Oct4 in } \\
\text { combination with 2-Me-5HT \& } \\
\text { D4476 }\end{array}$ & mouse & Hou 2013 \\
\hline Prostaglandin E2 & $\begin{array}{l}\text { EP4 (Prostaglandin E receptor } \\
\text { 4) agonist, increases cAMP } \\
\text { levels }\end{array}$ & reprogramming enhancer & mouse & Hou 2013 \\
\hline Rolipram & $\begin{array}{l}\text { PDE4 antagonist, causes an } \\
\text { increase in cAMP levels }\end{array}$ & reprogramming enhancer & mouse & Hou 2013 \\
\hline 8-Br-cAMP & PKA activator & reprogramming enhancer & human & Jung, Kim 2014 \\
\hline \multicolumn{5}{|c|}{$\begin{array}{c}\text { Sonic hedgehog signaling } \\
\text { activators }\end{array}$} \\
\hline Oxysterol (25-OHChl) & SMO agonist & can replace Sox $2, \mathrm{~K} 1 \mathrm{f} 4, \mathrm{c}-\mathrm{Myc}$ & mouse & Moon, Heo 2011 \\
\hline Purmorphamine & SMO agonist & can replace Sox $2, \mathrm{~K} 1 \mathrm{f} 4, \mathrm{c}-\mathrm{Myc}$ & mouse & Moon, Heo 2011 \\
\hline Sonic hedgehog (Shh) & Sonic hedgehog signaling & can replace Sox $2, \mathrm{~K} 1 \mathrm{f} 4, \mathrm{c}-\mathrm{Myc}$ & mouse & Moon, Heo 2011 \\
\hline \multicolumn{5}{|l|}{$\begin{array}{l}\text { Histone deacetylase } \\
\text { (HDAC) inhibitors }\end{array}$} \\
\hline Sodium butyrate (NaB) & HDAC inhibitor & reprogramming enhancer & $\begin{array}{l}\text { mouse, } \\
\text { human }\end{array}$ & Mali P, 2010 \\
\hline Valproic acid (VPA) & HDAC inhibitor & $\begin{array}{l}\text { reprogramming enhancer; can } \\
\text { replace c-Myc/Klf4 in human } \\
\text { fibroblasts }\end{array}$ & $\begin{array}{l}\text { mouse, } \\
\text { human }\end{array}$ & $\begin{array}{l}\text { Huangfu D, Maehr R, } \\
\text { 2008; Huangfu D, } \\
\text { Osafune K, 2008; Li Y } \\
2011\end{array}$ \\
\hline
\end{tabular}




\section{Table 1-1. Continued}

\begin{tabular}{|c|c|c|c|c|}
\hline Small Molecules & Function & Effects on Reprogramming & $\begin{array}{c}\text { Host } \\
\text { Animal }\end{array}$ & Reference \\
\hline $\begin{array}{l}\text { Suberoylanilide } \\
\text { hydroxamic acid (SAHA) }\end{array}$ & HDAC inhibitor & reprogramming enhancer & mouse & $\begin{array}{l}\text { Huangfu D, Maehr R, } \\
2008\end{array}$ \\
\hline Trichostain A (TSA) & HDAC inhibitor & reprogramming enhancer & mouse & $\begin{array}{l}\text { Huangfu D, Maehr R, } \\
2008\end{array}$ \\
\hline \multicolumn{5}{|l|}{$\begin{array}{l}\text { Histone demethylase } \\
\text { (HDM) inhibitor }\end{array}$} \\
\hline Tranylcypromine (Parnate) & H3K4 demethylation inhibitor & reprogramming enhancer & mouse & $\begin{array}{l}\text { Li W, Zhou H 2009; Li } \\
\text { MG } 2006\end{array}$ \\
\hline \multicolumn{5}{|l|}{$\begin{array}{l}\text { DNA methyltransferase } \\
\text { (DNMT) inhibitors }\end{array}$} \\
\hline $\begin{array}{l}\text { 5-Azacytidine (AZA, 5- } \\
\text { aza-CR) }\end{array}$ & DNMT inhibitor & reprogramming enhancer & mouse & $\begin{array}{l}\text { Mikkelson 2008; Papp, } \\
\text { Plath } 2013\end{array}$ \\
\hline RG108 & DNMT inhibitor & $\begin{array}{l}\text { can replace Sox } 2 \text { (with BIX) or } \\
\text { Oct } 4\end{array}$ & mouse & $\begin{array}{l}\text { Shi, Desponts 2008; Li } \\
\text { W, Ding S. 2010; Li, } \\
\text { Zhou } 2009\end{array}$ \\
\hline RSC133 & $\begin{array}{l}\text { DNMT inhibitor/histone } \\
\text { deacetylase inhibitor }\end{array}$ & reprogramming enhancer & human & Lee J 2012 \\
\hline \multicolumn{5}{|l|}{$\begin{array}{c}\text { Histone } \\
\text { methyltransferase } \\
\text { (HMT) inhibitor }\end{array}$} \\
\hline BIX-01294 (BIX) & G9a HMTase inhibitor & $\begin{array}{l}\text { reprogramming enhancer; can } \\
\text { replace Sox } 2\end{array}$ & mouse & Shi, Do 2008 \\
\hline \multicolumn{5}{|l|}{$\begin{array}{l}\text { Src family tyrosine } \\
\text { kinase inhibitors }\end{array}$} \\
\hline Dasatinib & $\begin{array}{l}\text { Src family tyrosine kinase } \\
\text { inhibitor }\end{array}$ & can replace Sox2 & mouse & Staerk, Lyssiotis 2011 \\
\hline iPY razine (iPY) & $\begin{array}{l}\text { Src family tyrosine kinase } \\
\text { inhibitor }\end{array}$ & can replace Sox 2 & mouse & Staerk, Lyssiotis 2011 \\
\hline
\end{tabular}




\section{Table 1-1. Continued}

\begin{tabular}{|c|c|c|c|c|}
\hline Small Molecules & Function & Effects on Reprogramming & $\begin{array}{c}\text { Host } \\
\text { Animal }\end{array}$ & Reference \\
\hline \multicolumn{5}{|l|}{$\begin{array}{c}\text { Src family tyrosine } \\
\text { kinase inhibitors cont'd. }\end{array}$} \\
\hline PP1 & $\begin{array}{l}\text { Src family tyrosine kinase } \\
\text { inhibitor }\end{array}$ & can replace Sox 2 & mouse & Staerk, Lyssiotis 2011 \\
\hline \multicolumn{5}{|l|}{ Miscellaneous } \\
\hline AMI-5 & $\begin{array}{l}\text { Protein arginine } \\
\text { methyltransferase inhibitor }\end{array}$ & $\begin{array}{l}\text { can replace Sox2, Klf4 (with A- } \\
83-01 \text { ) }\end{array}$ & mouse & Yuan, Wan 2011 \\
\hline D4476 & CK1 inhibitor & $\begin{array}{l}\text { can replace Oct } 4 \text { with FSK \& } \\
2-\mathrm{Me}-5 \mathrm{HT}\end{array}$ & mouse & Hou 2013 \\
\hline Compound B4 (TGF $\beta-R I)$ & ALK4 inhibitor & reprogramming enhancer & mouse & Li, Rana 2012 \\
\hline Compound B10 & P38 kinase inhibitor & reprogramming enhancer & mouse & Li, Rana 2012 \\
\hline Compound B8 & $\begin{array}{l}\text { inositol triphosphate 3-kinase } \\
\text { (IP3K) inhibitor }\end{array}$ & reprogramming enhancer & mouse & Li, Rana 2012 \\
\hline Rapamycin & mTOR inhibitor & reprogramming enhancer & mouse & Chen, Shen 2011 \\
\hline N-oxaloylglycine & prolyl-4-hydroxylase inhibitor & reprogramming enhancer & human & Zhu, Li 2010 \\
\hline Quercetin & $\begin{array}{l}\text { hypoxia inducible factor (HIF) } \\
\text { pathway activator }\end{array}$ & reprogramming enhancer & human & Zhu, Li 2010 \\
\hline Fructose 2,6-bisphosphate & $\begin{array}{l}\text { phosphofructokinase } 1 \\
\text { activator }\end{array}$ & reprogramming enhancer & human & Zhu, Li 2010 \\
\hline $\begin{array}{l}\text { PS48 (5-(4-Chloro- } \\
\text { phenyl)-3-phenyl-pent-2- } \\
\text { enoic acid) }\end{array}$ & $\begin{array}{l}\text { 3'-phosphoinositide-dependent } \\
\text { kinase } 1 \text { (PDK1) activator }\end{array}$ & reprogramming enhancer & human & Zhu, Li 2010 \\
\hline 2,4-dinitrophenol (DNP) & $\begin{array}{l}\text { oxidative phosphorylation } \\
\text { uncoupler }\end{array}$ & reprogramming enhancer & human & Zhu, Li 2010 \\
\hline TTNPB & Retinoic acid receptor ligand & reprogramming enhancer & mouse & Hou 2013 \\
\hline $\begin{array}{l}\text { 3-deazaneplanocin } \\
\text { (DZNep) }\end{array}$ & Epigenetic modulator & reprogramming enhancer & mouse & Hou 2013 \\
\hline
\end{tabular}




\section{CHAPTER 2. SMALL MOLECULE COMPOUNDS THAT MODULATE CELLULAR PATHWAYS TO PROMOTE IPSC PRODUCTION}

Several of the cellular pathways deregulated in human cancers are also linked to the production of iPSCs, and there is evidence to support the notion that some human cancers are a stem cell disease. Three critical signaling pathways involved in the chemical reprogramming of stem cells and cancer are TGF- $\beta$, Wnt, and FGF/MAPK/ERK. TGF- $\beta$, Wnt, and FGF/MAPK/ERK signaling critically regulate the reprogramming process (Hawkins, Joy et al. 2014), control stem cell differentiation (Wang and Chen 2015), and maintain the stem cell state (Dalton 2013). TGF- $\beta$ signaling specifically plays a critical role in regulating pluripotency and differentiation of ESCs (Itoh, Watabe et al. 2014). Glycogen synthase kinase 3 (GSK3) interacts with the Wnt signaling pathway and helps regulate cell fate determination (McCubrey, Steelman et al. 2014). GSK inhibitors maintain stem cell pluripotency and help generate iPSCs (Doble and Woodgett 2009). These key signaling pathways also have a significant function in cancer. Small molecule compounds targeting FGFR is an expanding topic in clinical oncology because FGF signaling is involved in many aspects of cancer biology (Heinzle, Sutterluty et al. 2011). Small molecule compounds have also been developed to target the TGF- $\beta$ signaling pathway (Principe, Doll et al. 2014) and the Wnt signaling pathway, given the aberrant activation of this pathway in various cancers (Zhang and Hao 2015).

Small molecule compounds capable of modulating cell-cycle signaling pathways to promote iPSC production using only a few transcription factors have recently been reviewed (Zhang, Yang et al. 2009, Green and Lee 2013). Small molecule inhibitors with these effects typically target either downstream protein kinases activated by the transcription factor or modify chromatin structure and thus directly affect transcription factor function. Specifically, the pharmacological inhibition of three key players, including the transforming growth factor (TGF)- $\beta$ receptor, glycogen synthase kinase 3 (GSK3)- $\beta$ and mitogen-activated protein kinase (MAPK), enhances somatic cell reprogramming (Sanges and Cosma 2010, Federation, Bradner et al. 2014, Jung, Kim et al. 2014).

\section{FGF/MAPK/ERK Signaling Pathway}

The MEK-MAPK/ERK (extracellular signal-regulated kinases) pathway is a protein kinase cascade that controls many cellular processes including induction of pluripotency (Sanges and Cosma 2010). MAPK regulates several transcription factors including c-Myc. ERK signaling has been shown to induce differentiation of pluripotent ESCs to a committed lineage through FGF stimulation (Kunath, Saba-El-Leil et al. 2007). Conversely, inhibition of the ERK pathway enhances reprogramming efficiency of mouse somatic cells to a pluripotent state. Indeed, inhibiting ERK1/2 with PD98059 (MAPK/ERK inhibitor) treatment results in increased Oct4-expression (Buehr and Smith 2003). Fibroblast growth factors (FGFs) play a key role in the proliferation and differentiation of a variety of cells, and can activate the MAPK/ERK pathway through 
MEK (MAPK/ERK kinase) activation. PD0325901 (PD) (1), a small molecule MEK (MAP3 kinase) inhibitor, promotes the efficiency of mouse and human iPSC (miPSC, hiPSC) reprogramming and late somatic cell reprogramming (after Oct4 activation). PD0325901 also inhibits the growth of non-iPSC colonies and supports the growth of reprogrammed iPSCs (Shi, Do et al. 2008, Silva, Barrandon et al. 2008) (Figure 2-1).

\section{TGF- $\beta$ Signaling Pathway}

Morphogens relating to TGF- $\beta$, including the bone morphogenetic proteins (BMPs), regulate stem cell fate commitment (Varga and Wrana 2005). BMP signaling, in conjunction with leukemia inhibiting factor (LIF) signaling, maintains pluripotency in mESCs (Ying, Nichols et al. 2003), whereas TGF- $\beta$ signaling maintains pluripotency in hESCs and mouse stem cells derived from the epiblast (EpiSCs) (Vallier, Mendjan et al. 2009). Recent studies discovered the important role of BMP signaling in the initial stage of reprogramming. BMP7 enhances reprogramming efficiency by increasing the number of reprogrammed colonies after MEFs are transduced with OSKM (Samavarchi-Tehrani, Golipour et al. 2010). The production of iPSCs from mouse fibroblasts requires a mesenchymal-to-epithelial transition (MET). Small molecule inhibitors of TGF- $\beta$ signaling facilitate MET, and therefore enhance reprogramming efficiency (Li, Liang et al. 2010).

Selective small molecule TGF- $\beta$ receptor inhibitors, including A83-01 (2), LY364947 (3), SB431542 (4), and 616452 (5) promote iPSC production preventing phosphorylation of intracellular SMAD proteins which is downstream of TGF-R (Figure 2-2). The combination of A-83-01 and PD0325901 enhanced the reprogramming efficiency of human keratinocytes transduced with either OSKM or OSK. Neonatal human epidermal keratinocytes (NHEKs), transduced with just OK, and treated with A83-01 and PD0325901, still generated iPSCs, albeit with lower efficiency (Zhu, Li et al. 2010). AMI-5, a protein arginine methyltransferase inhibitor, in combination with A8301, induced reprogramming of MEFs transduced with Oct4, and replaced Sox 2 during mouse somatic cell reprogramming. The generated miPSCs displayed similar pluripotency characteristics to mESCs (Yuan, Wan et al. 2011). LY-364947 was discovered to replace Sox 2 in miPSC generation (Ichida, Blanchard et al. 2009, Staerk, Lyssiotis et al. 2011). Furthermore, the compounds 616452 and SB431542 were able to substitute for Sox 2 during miPSC and hiPSC generation (Ichida, Blanchard et al. 2009, Li, Zhou et al. 2009, Li, Zhang et al. 2011, Wang, Xu et al. 2011). Inhibition of TGF- $\beta$ signaling leads to sustained transcription of Nanog, causing complete reprogramming (Attisano and Wrana 2002, Ichida, Blanchard et al. 2009).

The simultaneous inhibition of the TGF- $\beta$ and MAPK/ERK pathways using the small molecules SB431542 and PD0325901, in combination with OSKM, significantly enhances the reprogramming of human fibroblasts (Lin, Ambasudhan et al. 2009). Likewise, the dual inhibition of the TGF- $\beta$ and MAPK/ERK pathways in combination with parnate, a small molecule inhibitor of lysine-specific demethylase 1, and 


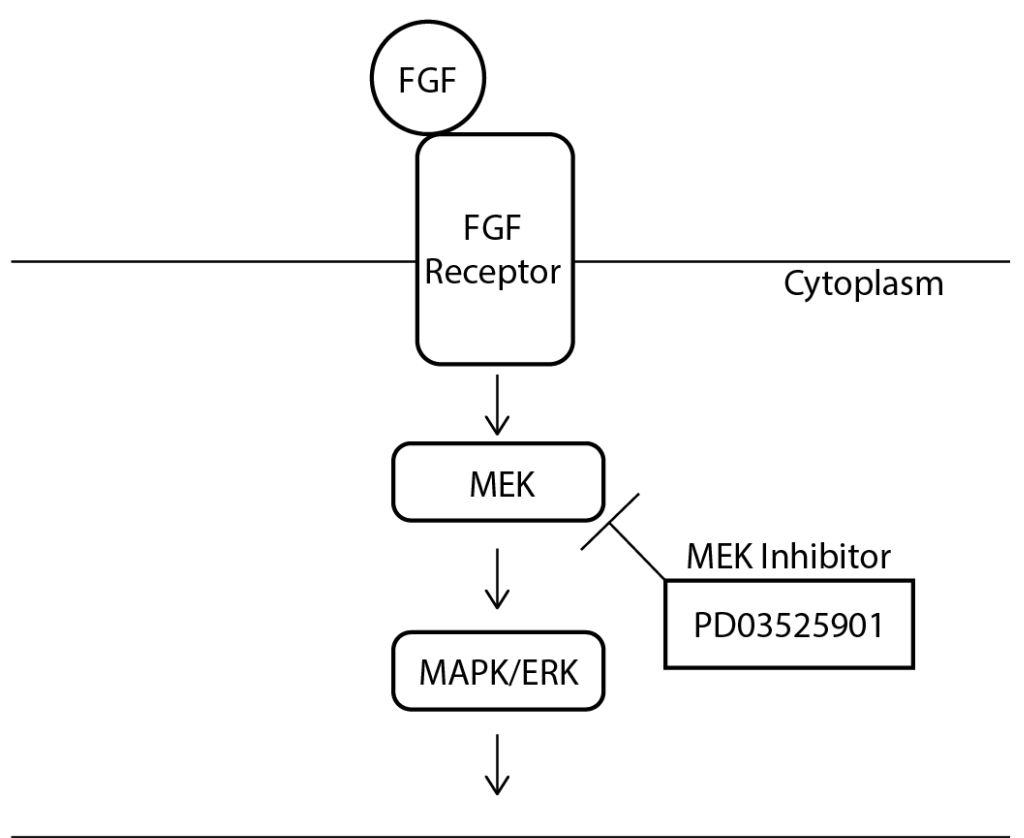

Nucleus

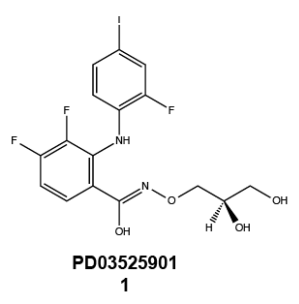

\section{Figure 2-1. FGF/MAPK/ERK Signaling Pathway}

The binding of fibroblast growth factor (FGF) to the cell surface FGF receptor (FGFR) activates the tyrosine kinase activity of the cytoplasmic domain of the FGFR and induces a protein kinase cascade, resulting in the activation of MEK and subsequent activation of another mitogen-activated protein kinase (MAPK). Activated MAPK now has the ability to activate transcription factors in the nucleus. However, inhibition of MEK through chemical manipulation deactivates the MAPK/ERK signaling pathway, yet triggers somatic cell reprogramming. 


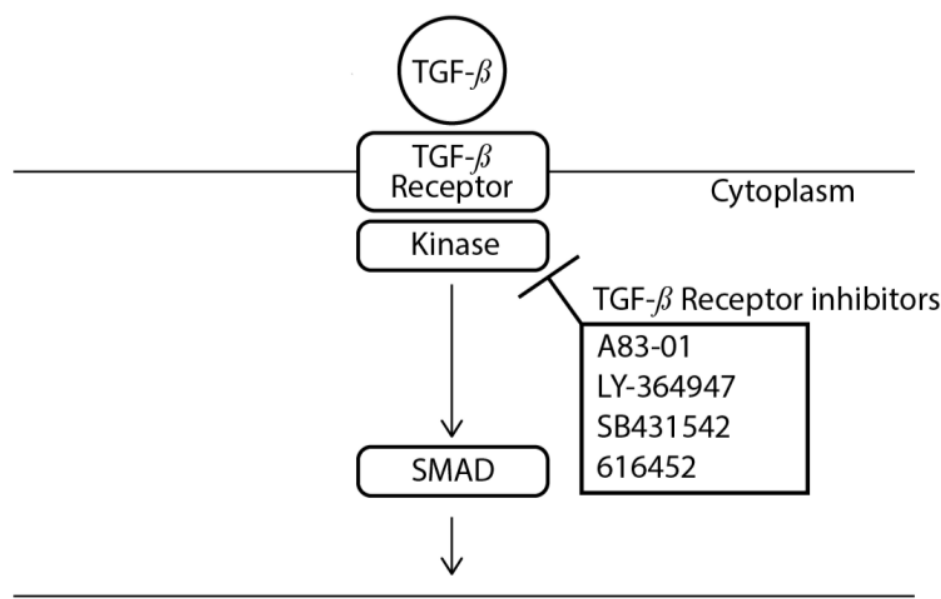

Nucleus
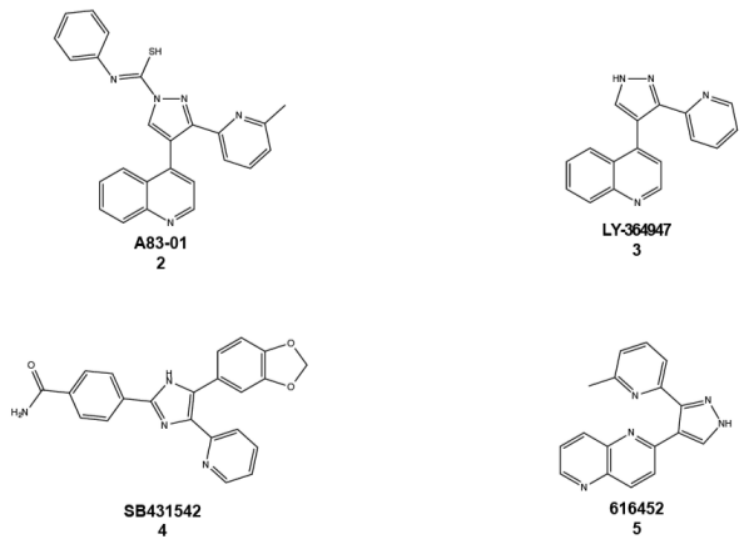

Figure 2-2. TGF- $\beta$ Signaling Pathway

SMADs are transcription factors that are activated in response to an extracellular TGF- $\beta$ ligand binding to membrane bound TGF- $\beta$ receptors. SMAD then enters the nucleus to act as a transcription factor for various genes. TGF- $\beta$ signaling plays an important role in reprogramming, and inhibitors of TGF- $\beta$ receptors can enhance reprogramming by functionally replacing key transgenic transcription factors. 
CHIR99021 (6), a GSK-3 $\beta$ small molecule inhibitor, promotes the reprogramming of human keratinocytes in the presence of Oct4 and Klf4 (Li, Zhou et al. 2009).

Oct4-only reprogramming has been achieved with several human somatic cell types when used in combination with small molecules. Oct4 transduced neonatal human epidermal keratinocytes (NHEKs), treated with sodium butyrate $(\mathrm{NaB})$, a histone deacetylase inhibitor, PS48, a small molecule activator of PDK1 (3'-phosphoinositidedependent kinase-1), and A-83-01, a selective TGF- $\beta$ receptor inhibitor, for four weeks, followed by continued treatment with $\mathrm{NaB}$, PS48, A-83-01 and PD0325901 for another four weeks, in addition to treatment with parnate and CHIR99021, generated iPSCs from adult epidermal keratinocytes. The generated iPSCs demonstrated characteristics similar to pluripotent hESCs (Zhu, Li et al. 2010). The combination of small molecule inhibitors of two key signaling pathways increases the efficiency of reprogramming by replacing defined transcription factors.

\section{Wnt Signaling Pathway}

The Wnt signaling pathway has been shown to have roles in maintaining $\mathrm{mESCs} / \mathrm{hESCs}$ pluripotency, in maintaining undifferentiated adult stem cells, and in promoting ESC self-renewal in various tissues. Wnt antagonists have also been shown to regulate hematopoietic stem cell fate decisions (Cain and Manilay 2013). Additionally, the activation of Wnt signaling in various types of cancer stem cells (CSCs) has been well researched (Reya and Clevers 2005), however the mechanism by which Wnt signaling regulates stem cell fate is not fully understood. Several Wnt inhibitors have been studied in pre-clinical trials that screened for compounds selectively toxic to cancer stem cells from breast cancers. The small molecule compound salinomycin, for example, induces epithelial differentiation of tumor stem cells and inhibits mammary tumor growth in vivo (Gupta, Onder et al. 2009) by preventing the phosphorylation of Wnt receptor, LPR6 (Lu, Choi et al. 2011).

Activation of Wnt signaling sustains the expression of Oct4, Rex1, and Nanog by antagonizing GSK3- $\beta$, a part of the $\beta$-catenin destruction complex. GSK3- $\beta$ antagonizing causes nuclear accumulation of $\beta$-catenin, an intracellular signaling molecule responsible for activation of reprogramming genes (Sato, Meijer et al. 2004, Ogawa, Nishinakamura et al. 2006, Singla, Schneider et al. 2006, Cai, Ye et al. 2007, Marson, Foreman et al. 2008, Ho, Papp et al. 2013, Holland, Klaus et al. 2013). Lithium Chloride (LiCl) and CHIR99021 (CHIR), small molecule GSK3- $\beta$ inhibitors, activate Wnt signaling (Figure 2-3). LiCl promotes reprogramming efficiency of somatic cells into both miPSCs and hiPSCs. LiCl also acts as an epigenetic modulator by down-regulating LSD1, an H3K4specific demethylase (Wang, Xu et al. 2011). CHIR was reported to induce the reprogramming of both mouse and human somatic cells in the absence of Sox 2 (Li, Zhou et al. 2009). CHIR was also reported to induce the reprogramming of MEFs transduced with only two transcription factors, Oct4 and Klf4. When used in combination with HDAC inhibitors valproic acid (VPA) and 616452, CHIR increased the reprogramming efficiency of MEFs transduced with Oct4 and Klf4 into miPSCs. Investigators even 


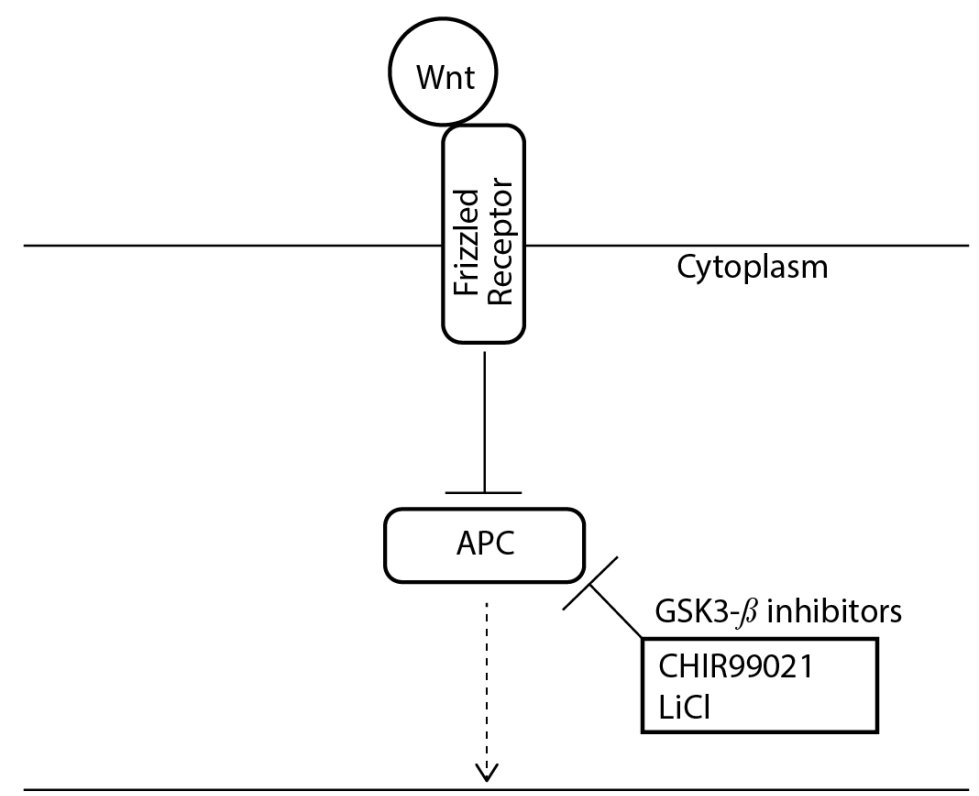

Nucleus

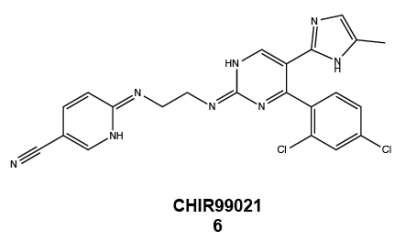

\section{Figure 2-3. Wnt Signaling Pathway}

The canonical Wnt pathway is activated by the binding of an extracellular Wnt-protein ligand to a trans-membrane Frizzled family receptor. $\beta$-catenin accumulates in the cytoplasm, translocates into the nucleus, and interacts with Tcf/Lef proteins to activate target genes. In the absence of Wnt stimulation, a destruction complex, including the protein glycogen synthase kinase 3-beta (GSK3- $\beta$ ) and adenomatosis polyposis coli (APC), degrades $\beta$-catenin by targeting it for ubiquitination. The Wnt signaling and $\beta$-catenin pathways secure the maintenance of self-renewal of mouse and human embryonic stem cells (mESCs, hESCs) through the inhibition of GSK3- $\beta$, and the subsequent nuclear accumulation of $\beta$-catenin. 
reported the generation of miPSCs from Oct4-only transduced MEFs in combination with VPA, CHIR99021, and 616452; however, the efficiency rate was low (Li, Zhang et al. 2011). Kenpaullone, has an established role as a GSK-3 $\beta$ or CDK inhibitor (Kenpaullone inhibits CDK1/cyclin B, CDK2/cyclin A, CDK2/cyclin E, CDK5/p25, and $\mathrm{CDK} 5 / \mathrm{cyclin} / \mathrm{p} 35)$, and can replace K1f4 to generate miPSCs that are identical to mESCs (Lyssiotis, Foreman et al. 2009).

Compound B6, (aurora kinase inhibitor) inhibits GSK3- $\beta$, and overall facilitates the reprogramming efficiency of somatic cells into miPSCs (Giorgetti, Montserrat et al. 2010). Compounds B8, an inositol triphosphate 3-kinase inhibitor, and B10, a P38 kinase inhibitor, enhance the efficiency of reprogramming into miPSCs. When combined, Compounds B6, B8, and B10 have a synergistic effect on reprogramming efficiency ( $\mathrm{Li}$ and Rana 2012). Compound B4, a TGF $\beta$-RI/Activin-receptor-like kinase 4 (ALK-4) inhibitor, also promotes reprogramming. Compound B4 can also replace Sox 2 when used in combination with a specific small molecule cocktail (Ichida, Blanchard et al. 2009, Maherali and Hochedlinger 2009, Li and Rana 2012).

Olanzapine, a D2/5-HT2 antagonist, enhances the differentiation of neural stem cells (NSCs) to oligodendrocyte-like cells (ODLCs) through inhibition of the $\beta$-catenin pathway. Olanzapine has positive prospects for the treatment of glioblastomas since GSLCs share similar characteristics to NSCs (Guo, Yang et al. 2015). Small molecules that target mediators of the Wnt signaling pathway, including the key mediator $\beta$-catenin, regulate the expression of target genes, influence cell fate, and overall enhance the efficiency of reprogramming.

\section{Sonic Hedgehog Homolog (SHH) Signaling Pathway}

The sonic hedgehog homolog signaling pathway plays a key role in regulating cellular reprogramming. The SHH pathway also helps to regulate the behaviors of cancer stem cells. The Smoothened protein (SMO) is a key component of the SHH pathway because it acts as a bridge between the Patched receptor (Ptch) and the intracellular Gli complex (Simeone 2008). When the Hh ligand binds to Patched, Smoothened is released and the SHH signaling pathway is activated. SMO antagonists, including Cyclopamine and vesmodigib (GDC-0449), inhibit the SHH signaling pathway by directly binding to Smoothened. Such small molecule compounds that target Smoothened have been reported to decrease the number of cancer stem cells and their growth. Cancer stem cells are a subpopulation of cancer cells within the tumor that have the ability to self-renew, proliferate, and differentiate. Inhibition of the SHH signaling pathway may therefore be beneficial for cancer treatment through the direct targeting of the cancer stem cell population (Merchant and Matsui 2010, Ailles and Siu 2011, Kelleher 2011, Perrot, Javelaud et al. 2013). Activation of the sonic hedgehog pathway has also been shown to lead to an intermediate cell type that expresses Sox2, Klf4, and c-Myc. The small molecule compounds, 25-hydroxycholesterol (25-OHChl) and purmorphamine (7) can reprogram mouse embryonic and adult fibroblasts into iPSCs in combination with Oct4 (Moon, Heo et al. 2011) (Figure 2-4). Other components of the SHH pathway, including 


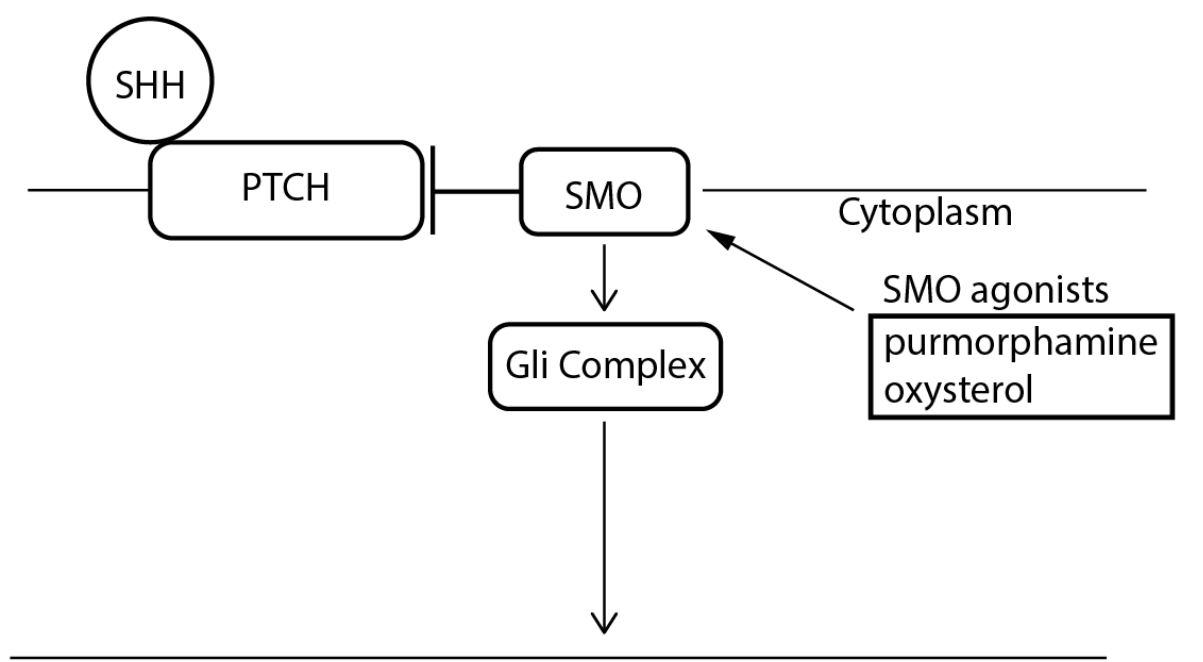

Nucleus

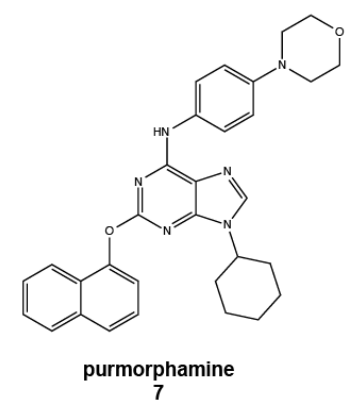

Figure 2-4. Sonic Hedgehog Homolog (SHH) Signaling Pathway

The Sonic hedgehog signaling pathway is stimulated when sonic hedgehog homolog $(\mathrm{SHH})$ binds to the Patched $(\mathrm{PTCH})$ receptor. In the absence of the SHH ligand, PTCH inhibits Smoothened (SMO), a G protein-coupled receptor (GPCR). SHH binding releases SMO inhibition, causing the activation of the GLI complex, a key regulator of the transcription of hedgehog target genes in the nucleus. Small molecule compounds that act as SMO agonists can activate the Sonic hedgehog signaling pathway and enhance somatic cell reprogramming. 
targets upstream of SMO, the Shh ligand, and targets downstream of SMO, like Gli transcription factors, can be inhibited. Although small molecule inhibitors exist for these targets, further investigation is required to determine their inhibitory effect on iPSC production. Potent small molecule modulators of the SHH pathway have been recently reviewed (Heretsch, Tzagkaroulaki et al. 2010).

\section{cAMP Signaling Pathway}

Activators of the cAMP signaling pathway can also induce cellular reprogramming. 2-methyl-5-hydroxytryptamine, a 2-Me-5HT; 5-HT3 agonist, Forskolin (FSK) (8), an adenylyl cyclase activator, and D4476 a casein kinase 1 inhibitor, can all act as chemical replacements for Oct4 in mouse cells (Hou, Li et al. 2013). Prostaglandin (9), an EP4 agonist, and Rolipram (10), a direct selective PDE4 inhibitor, promote late reprogramming in mouse cells (Hou, Li et al. 2013). 8-Bromoadenosine 3' 5 ', -cyclic monophosphate (8-Br-cAMP) (11) is a cAMP-dependent protein kinase activator that promotes reprogramming into hiPSCs (Jung, Kim et al. 2014). The downstream effects of these small molecules are to increase cellular cAMP production (Figure 2-5). cAMP levels have also been reported to be regulated by ascorbic acid (AA). AA is a competitive inhibitor of adenylate cyclase and therefore lowers the intracellular concentration of cAMP (Rahman, Al Frouh et al. 2014). Chemical modulation of the cAMP signaling pathway represents another fundamental mechanism controlling cellular reprogramming.

\section{Additional Signaling Pathway Small Molecule Modulators That Promote IPSC Production}

Additional mechanisms regulating reprogramming efficiency have been uncovered in multiple reports. Foremost, the inhibition of the mammalian target of rapamycin (mTOR) pathway by rapamycin, a mTOR inhibitor, enhances the reprogramming efficiency of somatic cells into miPSCs (Chen, Shen et al. 2011). TTNPB, a synthetic retinoic acid receptor ligand, also enhances reprogramming efficiency. Furthermore, when used in combination with other small molecule compounds, including VPA, CHIR, 616452, Parnate, DZNep, MEFs were successfully reprogrammed into miPSCs using TTNPB (Hou, Li et al. 2013). Fructose 2,6bisphosphate, a phosphofructokinase 1 activator, and N-oxaloylglycine, a prolyl-4hydroxylase inhibitor, can enhance the reprogramming efficiency to hiPSC when used in combination with OSKM (Zhu, Li et al. 2010). Inhibitors of Src family tyrosine kinase including, Dasatinib, iPY razine (iPY), and PP1 can replace Sox 2 during cellular reprogramming of MEFs into miPSCs (Staerk, Lyssiotis et al. 2011). The combination of BayK (a L-channel calcium agonist) and BIX01294 can replace Sox2 during the reprogramming of MEFs transduced with Oct4 and Klf4, into miPSCs (Shi, Desponts et al. 2008).

Interestingly, mechanistic studies have suggested that the modulation of cell metabolism from mitochondrial oxidation to glycolysis is an important factor during 


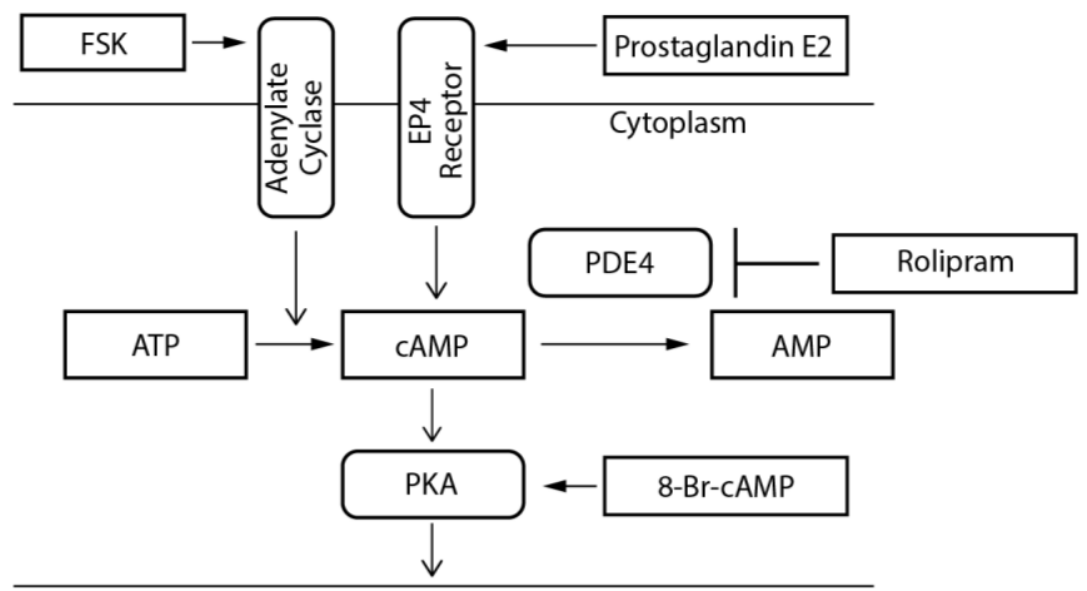

Nucleus

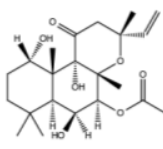

$\underset{8}{\mathrm{FSK}}$

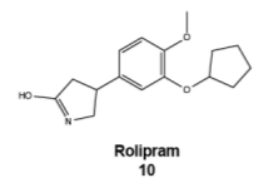

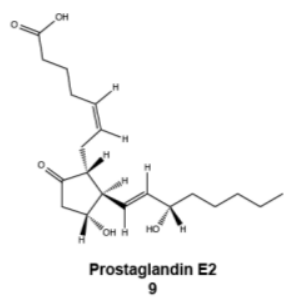

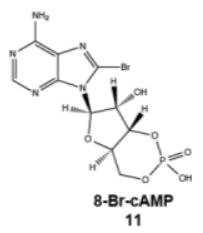

Figure 2-5. cAMP Signaling Pathway

Adenylyl cyclase is a 12-transmembrane glycoprotein that catalyzes the conversion of adenosine triphosphate (ATP) into cyclic adenosine monophosphate (cAMP). cAMP is an activator of protein kinase A (PKA), and this enzyme helps regulate gene expression. Phosphodiesterase (PDE4) is an enzyme that degrades cAMP to adenosine monophosphate (AMP), thereby inactivating PKA. Prostaglandin E2 is an agonist for EP4, a prostaglandin receptor. Chemical modulators of the cAMP signaling pathway can increase cellular cAMP levels and enhance somatic cell reprogramming. 
cellular reprogramming. DNP (2,4-dinitrophenol) modulates mitochondrial oxidation by inhibiting ATP phosphorylation. The combination of Oct4 expression and DNP was reported to enhance reprogramming efficiency of human primary somatic cells into iPSCs. Quercetin, a hypoxia-inducible factor (HIF) pathway activator, has been used to promote the reprogramming of human somatic cells to pluripotent stem cells by promoting glycolytic metabolism. However quercetin has multiple other targets and the mechanism of affecting reprogramming may be more complicated. The small molecule PS48, a PDK1 activator that leads to activation of AKT, has been suggested to work in a similar fashion. Collectively, these findings suggest that a metabolic switch to anaerobic glycolysis is a key step during iPSC reprogramming (Zhu, Li et al. 2010). The breadth of regulatory pathways required for efficient cellular reprogramming is supported by the scope of small molecule compounds being discovered. Chemical modulation of key regulatory pathways evidently represents a key step towards the ultimate goal of chemical reprogramming, however, epigenetic modulations is another fundamental tool for efficient cellular reprogramming. 


\section{CHAPTER 3. SMALL MOLECULE EPIGENETIC MODULATING COMPOUNDS THAT FACILIATE REPROGRAMMING EFFICIENCY DURING IPSC PRODUCTION}

Transient expression of the four specific transcription factors, OSKM, modifies chromatin structure and causes cellular plasticity to direct the reprogramming of fibroblasts to somatic cells (Efe, Hilcove et al. 2011, Kim, Efe et al. 2011). However, expression of a combination of OSKM, small molecules, and additional factors has not proven sufficient for complete pluripotency. Therefore, additional requirements are needed to overcome major epigenetic barriers that prevent cellular reprogramming (Hanna, Saha et al. 2009, Smith, Nachman et al. 2010).

Indeed, chromatin-modifying enzymes can be utilized to more efficiently generate iPSCs with fewer transcription factors. Several small molecules enhance the reprogramming of somatic cells into iPSCs by inhibiting epigenetic modifying enzymes, including DNA methyltransferases (DNMTs), histone methyltransferases (HMT), histone deacetylases (HDAC), and histone demethylases (HDM) (Figure 3-1). These small molecules, termed epigenetic modulating compounds, act as potent enhancers of iPSC generation in a target-specific manner. They modify chromatin structure causing subsequent changes to the epigenome. Chromatin remodeling is key for efficient reprogramming and has recently been reviewed (Plath and Lowry 2011). In order to generate fully reprogrammed colonies, changes in DNA methylation must occur in addition to structural changes allowing chromatin to be more accessible to transcriptional machinery. Indeed, DNA methylation has a significant role in maintaining epigenetic states (Mikkelsen, Hanna et al. 2008, Sridharan, Tchieu et al. 2009).

\section{DNA Methyltransferase (DNMT) Inhibitors}

Pluripotent stem cells have a less methylated epigenetic profile compared to somatic cells. Therefore, inhibition of DNMTs may enhance cellular reprogramming by reactivating the expression of previously repressed genes. 5-Azacytidine (5-aza-CR, AZA) (15) is a DNA demethylating agent that was first utilized in cellular reprogramming to convert fibroblasts into muscle cells (Taylor and Jones 1979). AZA was more recently shown to increase cellular plasticity and overall efficiency of cellular reprogramming of mouse fibroblasts and B lymphocytes into iPSCs. Indeed, AZA treatment caused a 4-fold increase in the number of ESC-like colonies (Mikkelsen, Hanna et al. 2008). More recently, AZA treatment of partially reprogrammed cells induced a stable transition to fully reprogrammed iPSCs (Papp and Plath 2013). RG108 (16), like AZA, is an inhibitor of DNMT enzymatic activity and has been shown to enhance the reprogramming efficiency of cells transduced with Oct4/K1f4 (in the absence of Sox2) (Li, Zhou et al. 2009). However, despite the effects of DNA methylation inhibitors, their mechanisms of action require further investigation. 

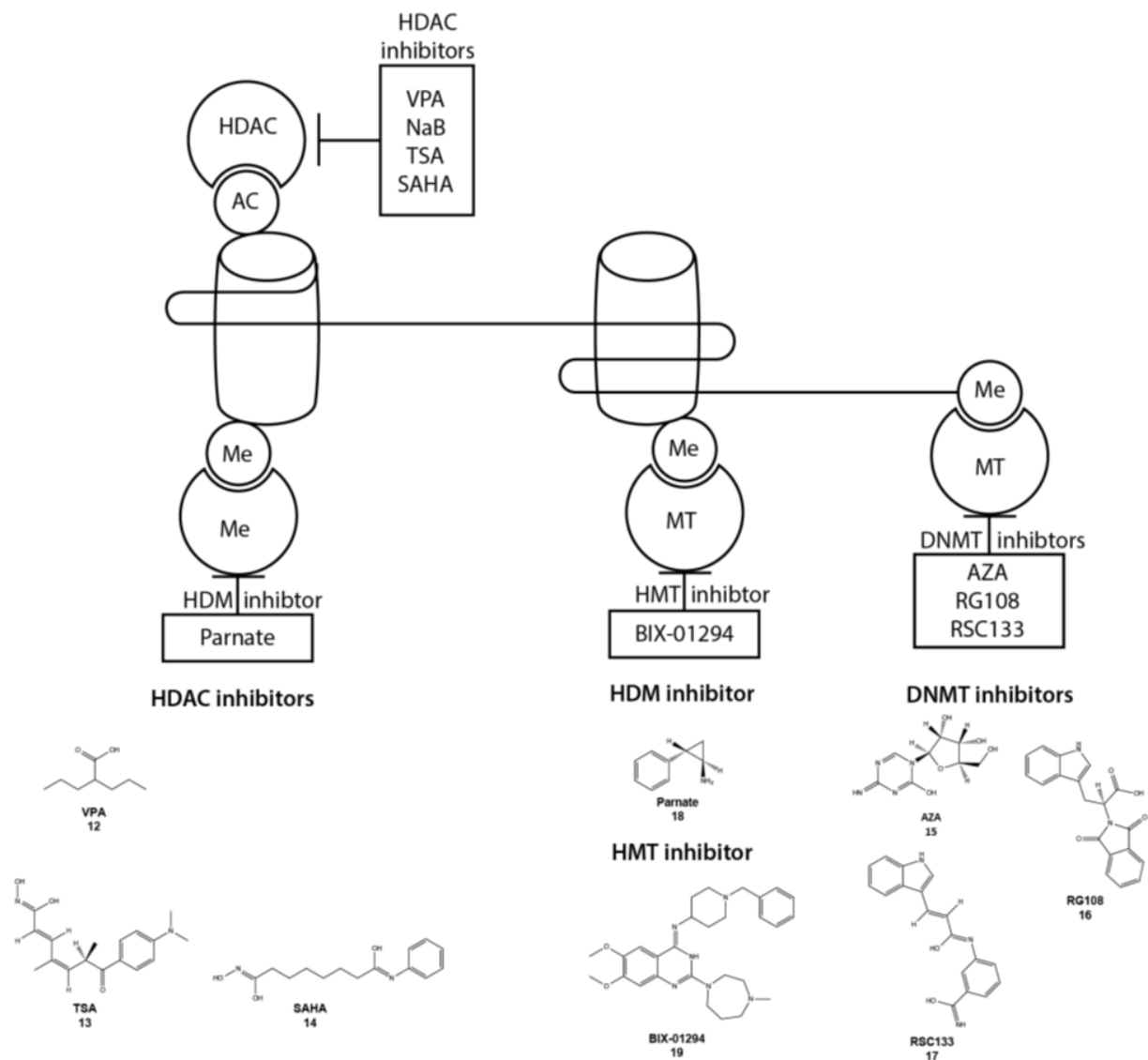

Figure 3-1. Small Molecule Epigenetic Compounds

Several small molecule inhibitors of epigenetic modifying enzymes, such as DNA methyltransferase (DNMT), histone deacetylase (HDAC), histone methyltransferase (HMT), and histone demethylase (HDM), modify chromatin structure to allow changes in the epigenome during reprogramming of somatic cells into iPSCs. DNMTs are enzymes that catalyze the transfer of one methyl group to DNA. Chemical inhibition of DNMTs may facilitate cellular reprogramming by re-expressing genes previously repressed by DNA methylation. Histone methylation also plays a key role in epigenetic gene regulation. HDACs are enzymes that remove acetyl groups from histones, allowing the histones to wrap DNA more tightly. HMTs are histone-modifying enzymes that catalyze the transfer of one, two, or three, methyl groups to lysine and arginine residues of histone proteins. HDMs are enzymes that remove methyl groups from histones. HDMs play an important role in epigenetic modification mechanisms because they control the methylation level that occurs on DNA and histones, and therefore regulate the chromatin state. 


\section{Histone Methyltransferase (HMT) Inhibitor}

The small molecule, BIX-01294 (BIX) (19) is an inhibitor of the G9a histone methyltransferase (G9a HMTase) (Kubicek, O'Sullivan et al. 2007). miPSCs generated from neural progenitor cells (NPCs) transduced with Oct4 and Klf4 and treated with BIX, exhibited similar characteristics to miPSCs generated using the four distinct transcription factors. This single small molecule compound could functionally replace c-Myc and Sox2. It was simultaneously reported that fetal NPCs virally transduced with Klf4, Sox2, and c-Myc, in combination with BIX treatment, generated iPSCs, at a low frequency however. Indeed, BIX may facilitate the active transcription of Oct4, as previous findings postulated (Shi, Do et al. 2008).

The knockdown of SUV39h1, a histone methyltransferase, has been shown to enhance reprogramming. This study also reported that the knockdown of DOT1L, a H3K79 histone methyltransferase, increased reprogramming efficiency and the number of iPSC colonies, and could functionally replace Klf4 and c-Myc. The DOL1L inhibitor, EPZ004777, was reported to selectively inhibit H3K79 methylation in mixed lineage leukemia cells and block the expression of leukemogenic genes. The expression of Nanog and Lin28, two factors that play important functional roles in the promotion of reprogramming, was reported to increase when used in conjunction with the Dot1L inhibitor during early reprogramming (Daigle, Olhava et al. 2011, Onder, Kara et al. 2012).

In combination with BIX, RG108 was reported to promote the reprogramming of MEFs transduced with Oct4 and Klf4 (Shi, Desponts et al. 2008, Li and Ding 2010). During the cellular reprogramming of mouse skeletal muscle cells into miPSCs, RG108 substituted for Oct4 when skeletal muscle cells endogenously expressed Sox2, Klf4, and c-Myc (Wang, Xu et al. 2011). More importantly, RG108 has been shown to enhance the reprogramming efficiency of human cells transduced with Oct4 and Klf4 (in the absence of Sox2) (Li, Zhou et al. 2009). RSC133 (17) is a small molecule compound that inhibits both histone deacetylase and DNA methyltransferase. By doing so, RSC133 enhanced the reprogramming of human somatic cells into iPSCs and sustained pluripotency in hiPSCs (Lee, Xia et al. 2012). During cellular reprogramming, epigenetic modulators modify chromatin structure by making it more open to changes in the epigenome and subsequently controlling cell fate.

\section{Histone Deacetylase (HDAC) Inhibitors}

Histone deacetylases (HDACs) represent a class of enzymes that can remove acetyl groups from histones causing DNA to tightly wrap around histones resulting in decreased gene expression. HDACs also exhibit non-histone functions. Histone acetyltransferases oppose HDAC enzymatic activity by acetylating histones, causing a loosening of the histone/DNA interaction resulting in increased gene expression. Small molecule HDAC inhibitors have been extensively studied to better understand their selectivity since some HDAC isoforms are associated with cellular functions in multiple 
diseases (Itoh, Suzuki et al. 2008, Bradner, West et al. 2010). Sodium butyrate (NaB) is a cell permeable small molecule HDAC inhibitor and was reported to enhance the reprogramming efficiency (15- to 51-fold increase) of human adult or fetal fibroblasts into iPSCs through either retroviral or piggyBac transposon vectors expressing 4 to 5 reprogramming genes. In the absence of either Klf4 or c-Myc, sodium butyrate exhibited an even greater increase in reprogramming efficiency ( $>100$ - to 200 -fold increase). The generated iPSCs reportedly expressed normal karyotypes and pluripotency. Treatment with sodium butyrate also enhanced histone $\mathrm{H} 3$ acetylation, promoter DNA demethylation, and the expression of endogenous pluripotency genes, including DPPA2 (Mali, Chou et al. 2010).

VPA (12) is a second HDAC inhibitor that enhances reprogramming efficiency by more than 100-fold and promotes cellular reprogramming in combination with Oct4, Sox2, and Klf4 (Huangfu, Maehr et al. 2008). VPA, in combination with three other small molecules, including, tranylcypromine (H3K4 demethylation inhibitor), CHIR99021 (GSK3- $\beta$ inhibitor) and 616452 (VC6T) (TGF- $\beta$ signaling inhibitor), induced the reprogramming of mouse fibroblasts in the presence of Oct4 ( $\mathrm{Li}$, Zhang et al. 2011). Three known HDAC inhibitors, suberoylanilide hydroxamic acid (SAHA) (14), trichostatin A (TSA) (13) and VPA were reported to improve reprogramming efficiency (Huangfu, Maehr et al. 2008). SAHA-PIP (SAHA is a histone deacetylase inhibitor and PIP is a sequence-specific DNA binding pyrrole-imidazole polyamide for modulating specific gene networks) targets and activates the Oct3/4 regulatory pluripotency genes in human dermal fibroblasts (Pandian, Sato et al. 2014). Small molecule compounds that modulate epigenetic enzymes, including HDAC inhibitors, can improve reprogramming efficiency or functionally replace reprogramming transcription factors.

\section{Histone Demethylase (HDM) Inhibitor}

Tranylcypromine (Parnate) (18) is an H3K4 demethylation inhibitor that enhances the reprogramming of mouse somatic cells into miPSCs by 20 -fold ( $\mathrm{Li}$, Zhang et al. 2011). Tranylcypromine treatment in mouse embryonic carcinoma cells was reported to activate endogenous Oct4 expression (Lee, Wynder et al. 2006). When CHIR99021 was combined with Parnate, CHIR99021 induced the reprogramming of human primary keratinocytes in the presence of Oct4 and Klf4 (Li, Zhou et al. 2009). DZNep (3-deazaneplanocin A) is another small molecule epigenetic modulator. When DZNep was added in the late phase of chemical reprogramming, Oct4 expression was significantly elevated. DZNep also significantly decreased DNA and H3K9 methylation at the Oct4 promoter, which may explain its role in Oct4 activation (Feldman, Gerson et al. 2006, Chen, Liu et al. 2013, Hou, Li et al. 2013). Histone H3 lysine 9 (H3K9) methylation (histone lysine methylation) is a determining factor for the pre-iPSC state, and its eradication was reported to lead to fully reprogrammed iPSCs (Chen, Liu et al. 2013). H3K9me3 inhibition can increase reprogramming efficiency because larger regions of $\mathrm{H} 3 \mathrm{~K} 9 \mathrm{me} 3$ are present in differentiated cells that have to be replaced with open chromatin in pluripotent cells (You and Han 2014). The removal of H3K9me3 serves as an epigenetic barrier in order to complete reprogramming and additional inhibitors should 
be investigated. Future studies should investigate other direct small molecule modulators of the epigenetic state in order to improve mouse and human somatic cell reprogramming. Remodeling of the epigenome is an integral step in cellular reprogramming. Epigenetic modifications facilitate cellular reprogramming by making cells more permissive to these epigenenomic changes. Consistent with this notion, compounds that modulate epigenetic enzymes, including HDAC, HMT, HDM, and DNMT, can improve reprogramming efficiency or replace specific transcription factors. 


\section{CHAPTER 4. CONCLUSION}

The production of induced pluripotent stem cells requires both lineage-specific transcription factors and a remodeled epigenetic landscape. Key drivers of the somatic state must efficiently be silenced in order for induction of pluripotency (Mikkelsen, Hanna et al. 2008, Pereira, Piccolo et al. 2010). Preliminary achievements of cellular reprogramming have enabled the generation of iPSCs from somatic cells by defined genetic factors. Interestingly, ESRRB, LIN28, DPPA2 and SALL4, are additional downstream factors that were shown to induce iPSCs from MEFs (Buganim, Faddah et al. 2012). However, genetic approaches to cellular reprogramming have concerns regarding safety and efficiency and additional barriers to the reprogramming process exist.

Small molecules have offered a complementary approach and chemically induced pluripotent stem cell technology has attracted enormous interest for its potential application in regenerative medicine. To date, Sodium butyrate, VPA, CHIR99021, LiCl, 616452, SB431542, PD325901, N-oxaloylglycine, PS48, 8-Br-cAMP, fructose 2,6bisphosphate, quercetin, and 2,4-dinitrophenol are all small molecule compounds used in hiPSC generation, but additional studies could examine whether other small molecules used in miPSC reprogramming are effective in hiPSC reprogramming. There is clear evidence that the modulation of key signaling pathways involved in iPSC induction, through the use of small molecules, improves reprogramming efficiency and iPSC quality, but the interplay between the signaling pathways requires better characterization for future clinical application. The investigation of small molecule compounds that promote cell cycle modifications is another promising avenue to investigate to lower reprogramming barriers and promote cellular reprogramming (Shi, Desponts et al. 2008, Hanna, Saha et al. 2009, Ruiz, Panopoulos et al. 2011). Indeed, the generation of chemically induced pluripotent stem cells has contributed to the area of stem cell research by influencing the direct reprogramming into functionally desirable cell types for clinical use. 


\section{LIST OF REFERENCES}

Ailles, L. and L. L. Siu (2011). "Targeting the Hedgehog pathway in cancer: can the spines be smoothened?" Clin Cancer Res 17(8): 2071-2073.

Anastasia, L., G. Pelissero, B. Venerando and G. Tettamanti (2010). "Cell reprogramming: expectations and challenges for chemistry in stem cell biology and regenerative medicine." Cell Death Differ 17(8): 1230-1237.

Anokye-Danso, F., C. M. Trivedi, D. Juhr, M. Gupta, Z. Cui, Y. Tian, Y. Zhang, W. Yang, P. J. Gruber, J. A. Epstein and E. E. Morrisey (2011). "Highly efficient miRNA-mediated reprogramming of mouse and human somatic cells to pluripotency." Cell Stem Cell 8(4): 376-388.

Attisano, L. and J. L. Wrana (2002). "Signal transduction by the TGF-beta superfamily." Science 296(5573): 1646-1647.

Bao, X., X. Zhu, B. Liao, C. Benda, Q. Zhuang, D. Pei, B. Qin and M. A. Esteban (2013). "MicroRNAs in somatic cell reprogramming." Curr Opin Cell Biol 25(2): 208214.

Bradner, J. E., N. West, M. L. Grachan, E. F. Greenberg, S. J. Haggarty, T. Warnow and R. Mazitschek (2010). "Chemical phylogenetics of histone deacetylases." Nat Chem Biol 6(3): 238-243.

Buehr, M. and A. Smith (2003). "Genesis of embryonic stem cells." Philos Trans R Soc Lond B Biol Sci 358(1436): 1397-1402; discussion 1402.

Buganim, Y., D. A. Faddah, A. W. Cheng, E. Itskovich, S. Markoulaki, K. Ganz, S. L. Klemm, A. van Oudenaarden and R. Jaenisch (2012). "Single-cell expression analyses during cellular reprogramming reveal an early stochastic and a late hierarchic phase." Cell 150(6): 1209-1222.

Cai, L., Z. Ye, B. Y. Zhou, P. Mali, C. Zhou and L. Cheng (2007). "Promoting human embryonic stem cell renewal or differentiation by modulating Wnt signal and culture conditions." Cell Res 17(1): 62-72.

Cain, C. J. and J. O. Manilay (2013). "Hematopoietic stem cell fate decisions are regulated by Wnt antagonists: comparisons and current controversies." Exp Hematol 41(1): 3-16.

Chen, J., H. Liu, J. Liu, J. Qi, B. Wei, J. Yang, H. Liang, Y. Chen, J. Chen, Y. Wu, L. Guo, J. Zhu, X. Zhao, T. Peng, Y. Zhang, S. Chen, X. Li, D. Li, T. Wang and D. Pei (2013). "H3K9 methylation is a barrier during somatic cell reprogramming into iPSCs." Nat Genet 45(1): 34-42. 
Chen, T., L. Shen, J. Yu, H. Wan, A. Guo, J. Chen, Y. Long, J. Zhao and G. Pei (2011). "Rapamycin and other longevity-promoting compounds enhance the generation of mouse induced pluripotent stem cells." Aging Cell 10(5): 908-911.

Chen, X., V. B. Vega and H. H. Ng (2008). "Transcriptional regulatory networks in embryonic stem cells." Cold Spring Harb Symp Quant Biol 73: 203-209.

Chen, X., H. Xu, P. Yuan, F. Fang, M. Huss, V. B. Vega, E. Wong, Y. L. Orlov, W. Zhang, J. Jiang, Y. H. Loh, H. C. Yeo, Z. X. Yeo, V. Narang, K. R. Govindarajan, B. Leong, A. Shahab, Y. Ruan, G. Bourque, W. K. Sung, N. D. Clarke, C. L. Wei and H. H. Ng (2008). "Integration of external signaling pathways with the core transcriptional network in embryonic stem cells." Cell 133(6): 1106-1117.

Cho, H. J., C. S. Lee, Y. W. Kwon, J. S. Paek, S. H. Lee, J. Hur, E. J. Lee, T. Y. Roh, I. S. Chu, S. H. Leem, Y. Kim, H. J. Kang, Y. B. Park and H. S. Kim (2010). "Induction of pluripotent stem cells from adult somatic cells by protein-based reprogramming without genetic manipulation." Blood 116(3): 386-395.

Daigle, S. R., E. J. Olhava, C. A. Therkelsen, C. R. Majer, C. J. Sneeringer, J. Song, L. D. Johnston, M. P. Scott, J. J. Smith, Y. Xiao, L. Jin, K. W. Kuntz, R. Chesworth, M. P. Moyer, K. M. Bernt, J. C. Tseng, A. L. Kung, S. A. Armstrong, R. A. Copeland, V. M. Richon and R. M. Pollock (2011). "Selective killing of mixed lineage leukemia cells by a potent small-molecule DOT1L inhibitor." Cancer Cell 20(1): 53-65.

Dalton, S. (2013). "Signaling networks in human pluripotent stem cells." Curr Opin Cell Biol 25(2): 241-246.

Doble, B. W. and J. R. Woodgett (2009). "Exploring pluripotency with chemical genetics." Cell Stem Cell 4(2): 98-100.

Efe, J. A., S. Hilcove, J. Kim, H. Zhou, K. Ouyang, G. Wang, J. Chen and S. Ding (2011). "Conversion of mouse fibroblasts into cardiomyocytes using a direct reprogramming strategy." Nat Cell Biol 13(3): 215-222.

Esteban, M. A., T. Wang, B. Qin, J. Yang, D. Qin, J. Cai, W. Li, Z. Weng, J. Chen, S. Ni, K. Chen, Y. Li, X. Liu, J. Xu, S. Zhang, F. Li, W. He, K. Labuda, Y. Song, A. Peterbauer, S. Wolbank, H. Redl, M. Zhong, D. Cai, L. Zeng and D. Pei (2010). "Vitamin C enhances the generation of mouse and human induced pluripotent stem cells." Cell Stem Cell 6(1): 71-79.

Federation, A. J., J. E. Bradner and A. Meissner (2014). "The use of small molecules in somatic-cell reprogramming." Trends Cell Biol 24(3): 179-187. 
Feldman, N., A. Gerson, J. Fang, E. Li, Y. Zhang, Y. Shinkai, H. Cedar and Y. Bergman (2006). "G9a-mediated irreversible epigenetic inactivation of Oct-3/4 during early embryogenesis." Nat Cell Biol 8(2): 188-194.

Feng, B., J. H. Ng, J. C. Heng and H. H. Ng (2009). "Molecules that promote or enhance reprogramming of somatic cells to induced pluripotent stem cells." Cell Stem Cell 4(4): 301-312.

Firestone, A. J. and J. K. Chen (2010). "Controlling destiny through chemistry: smallmolecule regulators of cell fate." ACS Chem Biol 5(1): 15-34.

Giorgetti, A., N. Montserrat, I. Rodriguez-Piza, C. Azqueta, A. Veiga and J. C. Izpisua Belmonte (2010). "Generation of induced pluripotent stem cells from human cord blood cells with only two factors: Oct4 and Sox2." Nat Protoc 5(4): 811-820.

Green, E. M. and R. T. Lee (2013). "Proteins and small molecules for cellular regenerative medicine." Physiol Rev 93(1): 311-325.

Gross, B., M. Sgodda, M. Rasche, A. Schambach, G. Gohring, B. Schlegelberger, B. Greber, T. Linden, D. Reinhardt, T. Cantz and J. H. Klusmann (2013). "Improved generation of patient-specific induced pluripotent stem cells using a chemicallydefined and matrigel-based approach." Curr Mol Med 13(5): 765-776.

Guo, Q. H., H. J. Yang and S. D. Wang (2015). "Olanzapine inhibits the proliferation and induces the differentiation of glioma stem-like cells through modulating the Wnt signaling pathway in vitro." Eur Rev Med Pharmacol Sci 19(13): 2406-2415.

Gupta, P. B., T. T. Onder, G. Jiang, K. Tao, C. Kuperwasser, R. A. Weinberg and E. S. Lander (2009). "Identification of selective inhibitors of cancer stem cells by highthroughput screening." Cell 138(4): 645-659.

Hanna, J., K. Saha, B. Pando, J. van Zon, C. J. Lengner, M. P. Creyghton, A. van Oudenaarden and R. Jaenisch (2009). "Direct cell reprogramming is a stochastic process amenable to acceleration." Nature 462(7273): 595-601.

Hawkins, K., S. Joy and T. McKay (2014). "Cell signalling pathways underlying induced pluripotent stem cell reprogramming." World J Stem Cells 6(5): 620-628.

Heinzle, C., H. Sutterluty, M. Grusch, B. Grasl-Kraupp, W. Berger and B. Marian (2011). "Targeting fibroblast-growth-factor-receptor-dependent signaling for cancer therapy." Expert Opin Ther Targets 15(7): 829-846.

Heretsch, P., L. Tzagkaroulaki and A. Giannis (2010). "Modulators of the hedgehog signaling pathway." Bioorg Med Chem 18(18): 6613-6624. 
Higuchi, A., Q. D. Ling, S. S. Kumar, M. A. Munusamy, A. A. Alarfaj, Y. Chang, S. H. Kao, K. C. Lin, H. C. Wang and A. Umezawa (2015). "Generation of pluripotent stem cells without the use of genetic material." Lab Invest 95(1): 26-42.

Ho, R., B. Papp, J. A. Hoffman, B. J. Merrill and K. Plath (2013). "Stage-specific regulation of reprogramming to induced pluripotent stem cells by Wnt signaling and T cell factor proteins." Cell Rep 3(6): 2113-2126.

Holland, J. D., A. Klaus, A. N. Garratt and W. Birchmeier (2013). "Wnt signaling in stem and cancer stem cells." Curr Opin Cell Biol 25(2): 254-264.

Hou, P., Y. Li, X. Zhang, C. Liu, J. Guan, H. Li, T. Zhao, J. Ye, W. Yang, K. Liu, J. Ge, J. Xu, Q. Zhang, Y. Zhao and H. Deng (2013). "Pluripotent stem cells induced from mouse somatic cells by small-molecule compounds." Science 341(6146): 651-654.

Huangfu, D., R. Maehr, W. Guo, A. Eijkelenboom, M. Snitow, A. E. Chen and D. A. Melton (2008). "Induction of pluripotent stem cells by defined factors is greatly improved by small-molecule compounds." Nat Biotechnol 26(7): 795-797.

Huangfu, D., K. Osafune, R. Maehr, W. Guo, A. Eijkelenboom, S. Chen, W. Muhlestein and D. A. Melton (2008). "Induction of pluripotent stem cells from primary human fibroblasts with only Oct4 and Sox2." Nat Biotechnol 26(11): 1269-1275.

Ichida, J. K., J. Blanchard, K. Lam, E. Y. Son, J. E. Chung, D. Egli, K. M. Loh, A. C. Carter, F. P. Di Giorgio, K. Koszka, D. Huangfu, H. Akutsu, D. R. Liu, L. L. Rubin and K. Eggan (2009). "A small-molecule inhibitor of tgf-Beta signaling replaces sox 2 in reprogramming by inducing nanog." Cell Stem Cell 5(5): 491503.

Itoh, F., T. Watabe and K. Miyazono (2014). "Roles of TGF-beta family signals in the fate determination of pluripotent stem cells." Semin Cell Dev Biol 32: 98-106.

Itoh, Y., T. Suzuki and N. Miyata (2008). "Isoform-selective histone deacetylase inhibitors." Curr Pharm Des 14(6): 529-544.

Jaenisch, R. and R. Young (2008). "Stem cells, the molecular circuitry of pluripotency and nuclear reprogramming." Cell 132(4): 567-582.

Jung, D. W., W. H. Kim and D. R. Williams (2014). "Reprogram or reboot: small molecule approaches for the production of induced pluripotent stem cells and direct cell reprogramming." ACS Chem Biol 9(1): 80-95.

Kelleher, F. C. (2011). "Hedgehog signaling and therapeutics in pancreatic cancer." Carcinogenesis 32(4): 445-451. 
Kim, D., C. H. Kim, J. I. Moon, Y. G. Chung, M. Y. Chang, B. S. Han, S. Ko, E. Yang, K. Y. Cha, R. Lanza and K. S. Kim (2009). "Generation of human induced pluripotent stem cells by direct delivery of reprogramming proteins." Cell Stem Cell 4(6): 472-476.

Kim, J., J. Chu, X. Shen, J. Wang and S. H. Orkin (2008). "An extended transcriptional network for pluripotency of embryonic stem cells." Cell 132(6): 1049-1061.

Kim, J., J. A. Efe, S. Zhu, M. Talantova, X. Yuan, S. Wang, S. A. Lipton, K. Zhang and S. Ding (2011). "Direct reprogramming of mouse fibroblasts to neural progenitors." Proc Natl Acad Sci U S A 108(19): 7838-7843.

Kim, J., A. J. Woo, J. Chu, J. W. Snow, Y. Fujiwara, C. G. Kim, A. B. Cantor and S. H. Orkin (2010). "A Myc network accounts for similarities between embryonic stem and cancer cell transcription programs." Cell 143(2): 313-324.

Kubicek, S., R. J. O'Sullivan, E. M. August, E. R. Hickey, Q. Zhang, M. L. Teodoro, S. Rea, K. Mechtler, J. A. Kowalski, C. A. Homon, T. A. Kelly and T. Jenuwein (2007). "Reversal of H3K9me2 by a small-molecule inhibitor for the G9a histone methyltransferase." Mol Cell 25(3): 473-481.

Kulcenty, K., J. Wroblewska, S. Mazurek, E. Liszewska and J. Jaworski (2015). "Molecular mechanisms of induced pluripotency." Contemp Oncol (Pozn) 19(1A): A22-29.

Kunath, T., M. K. Saba-El-Leil, M. Almousailleakh, J. Wray, S. Meloche and A. Smith (2007). "FGF stimulation of the Erk1/2 signalling cascade triggers transition of pluripotent embryonic stem cells from self-renewal to lineage commitment." Development 134(16): 2895-2902.

Lee, J., Y. Xia, M. Y. Son, G. Jin, B. Seol, M. J. Kim, M. J. Son, M. Do, M. Lee, D. Kim, K. Lee and Y. S. Cho (2012). "A novel small molecule facilitates the reprogramming of human somatic cells into a pluripotent state and supports the maintenance of an undifferentiated state of human pluripotent stem cells." Angew Chem Int Ed Engl 51(50): 12509-12513.

Lee, M. G., C. Wynder, D. M. Schmidt, D. G. McCafferty and R. Shiekhattar (2006). "Histone H3 lysine 4 demethylation is a target of nonselective antidepressive medications." Chem Biol 13(6): 563-567.

Li, R., J. Liang, S. Ni, T. Zhou, X. Qing, H. Li, W. He, J. Chen, F. Li, Q. Zhuang, B. Qin, J. Xu, W. Li, J. Yang, Y. Gan, D. Qin, S. Feng, H. Song, D. Yang, B. Zhang, L. Zeng, L. Lai, M. A. Esteban and D. Pei (2010). "A mesenchymal-to-epithelial transition initiates and is required for the nuclear reprogramming of mouse fibroblasts." Cell Stem Cell 7(1): 51-63. 
Li, W. and S. Ding (2010). "Small molecules that modulate embryonic stem cell fate and somatic cell reprogramming." Trends Pharmacol Sci 31(1): 36-45.

Li, W., K. Jiang and S. Ding (2012). "Concise review: A chemical approach to control cell fate and function." Stem Cells 30(1): 61-68.

Li, W., H. Zhou, R. Abujarour, S. Zhu, J. Young Joo, T. Lin, E. Hao, H. R. Scholer, A. Hayek and S. Ding (2009). "Generation of human-induced pluripotent stem cells in the absence of exogenous Sox2." Stem Cells 27(12): 2992-3000.

Li, Y., Q. Zhang, X. Yin, W. Yang, Y. Du, P. Hou, J. Ge, C. Liu, W. Zhang, X. Zhang, Y. Wu, H. Li, K. Liu, C. Wu, Z. Song, Y. Zhao, Y. Shi and H. Deng (2011).

"Generation of iPSCs from mouse fibroblasts with a single gene, Oct4, and small molecules." Cell Res 21(1): 196-204.

Li, Z. and T. M. Rana (2012). "A kinase inhibitor screen identifies small-molecule enhancers of reprogramming and iPS cell generation." Nat Commun 3: 1085.

Li, Z., C. S. Yang, K. Nakashima and T. M. Rana (2011). "Small RNA-mediated regulation of iPS cell generation." EMBO J 30(5): 823-834.

Lin, T., R. Ambasudhan, X. Yuan, W. Li, S. Hilcove, R. Abujarour, X. Lin, H. S. Hahm, E. Hao, A. Hayek and S. Ding (2009). "A chemical platform for improved induction of human iPSCs." Nat Methods 6(11): 805-808.

Lin, T., C. Chao, S. Saito, S. J. Mazur, M. E. Murphy, E. Appella and Y. Xu (2005). "p53 induces differentiation of mouse embryonic stem cells by suppressing Nanog expression." Nat Cell Biol 7(2): 165-171.

Lu, D., M. Y. Choi, J. Yu, J. E. Castro, T. J. Kipps and D. A. Carson (2011). "Salinomycin inhibits Wnt signaling and selectively induces apoptosis in chronic lymphocytic leukemia cells." Proc Natl Acad Sci U S A 108(32): 13253-13257.

Lu, J., X. Kong, C. Luo and K. K. Li (2013). "Application of epigenome-modifying small molecules in induced pluripotent stem cells." Med Res Rev 33(4): 790-822.

Lukaszewicz, A. I., M. K. McMillan and M. Kahn (2010). "Small molecules and stem cells. Potency and lineage commitment: the new quest for the fountain of youth." J Med Chem 53(9): 3439-3453.

Lyssiotis, C. A., R. K. Foreman, J. Staerk, M. Garcia, D. Mathur, S. Markoulaki, J. Hanna, L. L. Lairson, B. D. Charette, L. C. Bouchez, M. Bollong, C. Kunick, A. Brinker, C. Y. Cho, P. G. Schultz and R. Jaenisch (2009). "Reprogramming of murine fibroblasts to induced pluripotent stem cells with chemical complementation of Klf4." Proc Natl Acad Sci U S A 106(22): 8912-8917. 
Maherali, N. and K. Hochedlinger (2009). "Tgfbeta signal inhibition cooperates in the induction of iPSCs and replaces Sox2 and cMyc." Curr Biol 19(20): 1718-1723.

Mali, P., B. K. Chou, J. Yen, Z. Ye, J. Zou, S. Dowey, R. A. Brodsky, J. E. Ohm, W. Yu, S. B. Baylin, K. Yusa, A. Bradley, D. J. Meyers, C. Mukherjee, P. A. Cole and L. Cheng (2010). "Butyrate greatly enhances derivation of human induced pluripotent stem cells by promoting epigenetic remodeling and the expression of pluripotency-associated genes." Stem Cells 28(4): 713-720.

Marson, A., R. Foreman, B. Chevalier, S. Bilodeau, M. Kahn, R. A. Young and R. Jaenisch (2008). "Wnt signaling promotes reprogramming of somatic cells to pluripotency." Cell Stem Cell 3(2): 132-135.

McCubrey, J. A., L. S. Steelman, F. E. Bertrand, N. M. Davis, M. Sokolosky, S. L. Abrams, G. Montalto, A. B. D'Assoro, M. Libra, F. Nicoletti, R. Maestro, J. Basecke, D. Rakus, A. Gizak, Z. N. Demidenko, L. Cocco, A. M. Martelli and M. Cervello (2014). "GSK-3 as potential target for therapeutic intervention in cancer." Oncotarget 5(10): 2881-2911.

Merchant, A. A. and W. Matsui (2010). "Targeting Hedgehog--a cancer stem cell pathway." Clin Cancer Res 16(12): 3130-3140.

Mikkelsen, T. S., J. Hanna, X. Zhang, M. Ku, M. Wernig, P. Schorderet, B. E. Bernstein, R. Jaenisch, E. S. Lander and A. Meissner (2008). "Dissecting direct reprogramming through integrative genomic analysis." Nature 454(7200): 49-55.

Moon, J. H., J. S. Heo, J. S. Kim, E. K. Jun, J. H. Lee, A. Kim, J. Kim, K. Y. Whang, Y. K. Kang, S. Yeo, H. J. Lim, D. W. Han, D. W. Kim, S. Oh, B. S. Yoon, H. R. Scholer and S. You (2011). "Reprogramming fibroblasts into induced pluripotent stem cells with Bmi1." Cell Res 21(9): 1305-1315.

Ogawa, K., R. Nishinakamura, Y. Iwamatsu, D. Shimosato and H. Niwa (2006). "Synergistic action of Wnt and LIF in maintaining pluripotency of mouse ES cells." Biochem Biophys Res Commun 343(1): 159-166.

Okita, K., T. Ichisaka and S. Yamanaka (2007). "Generation of germline-competent induced pluripotent stem cells." Nature 448(7151): 313-317.

Okita, K., Y. Matsumura, Y. Sato, A. Okada, A. Morizane, S. Okamoto, H. Hong, M. Nakagawa, K. Tanabe, K. Tezuka, T. Shibata, T. Kunisada, M. Takahashi, J. Takahashi, H. Saji and S. Yamanaka (2011). "A more efficient method to generate integration-free human iPS cells." Nat Methods 8(5): 409-412.

Okita, K., M. Nakagawa, H. Hyenjong, T. Ichisaka and S. Yamanaka (2008). "Generation of mouse induced pluripotent stem cells without viral vectors." Science 322(5903): 949-953. 
Onder, T. T., N. Kara, A. Cherry, A. U. Sinha, N. Zhu, K. M. Bernt, P. Cahan, B. O. Marcarci, J. Unternaehrer, P. B. Gupta, E. S. Lander, S. A. Armstrong and G. Q. Daley (2012). "Chromatin-modifying enzymes as modulators of reprogramming." Nature 483(7391): 598-602.

Pandian, G. N., S. Sato, C. Anandhakumar, J. Taniguchi, K. Takashima, J. Syed, L. Han, A. Saha, T. Bando, H. Nagase and H. Sugiyama (2014). "Identification of a small molecule that turns ON the pluripotency gene circuitry in human fibroblasts." ACS Chem Biol 9(12): 2729-2736.

Papp, B. and K. Plath (2013). "Epigenetics of reprogramming to induced pluripotency." Cell 152(6): 1324-1343.

Pereira, C. F., F. M. Piccolo, T. Tsubouchi, S. Sauer, N. K. Ryan, L. Bruno, D. Landeira, J. Santos, A. Banito, J. Gil, H. Koseki, M. Merkenschlager and A. G. Fisher (2010). "ESCs require PRC2 to direct the successful reprogramming of differentiated cells toward pluripotency." Cell Stem Cell 6(6): 547-556.

Perrot, C. Y., D. Javelaud and A. Mauviel (2013). "Overlapping activities of TGF-beta and Hedgehog signaling in cancer: therapeutic targets for cancer treatment." Pharmacol Ther 137(2): 183-199.

Plath, K. and W. E. Lowry (2011). "Progress in understanding reprogramming to the induced pluripotent state." Nat Rev Genet 12(4): 253-265.

Polo, J. M., E. Anderssen, R. M. Walsh, B. A. Schwarz, C. M. Nefzger, S. M. Lim, M. Borkent, E. Apostolou, S. Alaei, J. Cloutier, O. Bar-Nur, S. Cheloufi, M. Stadtfeld, M. E. Figueroa, D. Robinton, S. Natesan, A. Melnick, J. Zhu, S. Ramaswamy and K. Hochedlinger (2012). "A molecular roadmap of reprogramming somatic cells into iPS cells." Cell 151(7): 1617-1632.

Principe, D. R., J. A. Doll, J. Bauer, B. Jung, H. G. Munshi, L. Bartholin, B. Pasche, C. Lee and P. J. Grippo (2014). "TGF-beta: duality of function between tumor prevention and carcinogenesis." J Natl Cancer Inst 106(2): djt369.

Rabinovich, P. M. and S. M. Weissman (2013). "Cell engineering with synthetic messenger RNA." Methods Mol Biol 969: 3-28.

Rahman, F., F. Al Frouh, B. Bordignon, M. Fraterno, J. F. Landrier, F. Peiretti and M. Fontes (2014). "Ascorbic acid is a dose-dependent inhibitor of adipocyte differentiation, probably by reducing cAMP pool." Front Cell Dev Biol 2: 29.

Reya, T. and H. Clevers (2005). "Wnt signalling in stem cells and cancer." Nature 434(7035): 843-850. 
Rowland, B. D., R. Bernards and D. S. Peeper (2005). "The KLF4 tumour suppressor is a transcriptional repressor of p53 that acts as a context-dependent oncogene." Nat Cell Biol 7(11): 1074-1082.

Ruiz, S., A. D. Panopoulos, A. Herrerias, K. D. Bissig, M. Lutz, W. T. Berggren, I. M. Verma and J. C. Izpisua Belmonte (2011). "A high proliferation rate is required for cell reprogramming and maintenance of human embryonic stem cell identity." Curr Biol 21(1): 45-52.

Samavarchi-Tehrani, P., A. Golipour, L. David, H. K. Sung, T. A. Beyer, A. Datti, K. Woltjen, A. Nagy and J. L. Wrana (2010). "Functional genomics reveals a BMPdriven mesenchymal-to-epithelial transition in the initiation of somatic cell reprogramming." Cell Stem Cell 7(1): 64-77.

Sanges, D. and M. P. Cosma (2010). "Reprogramming cell fate to pluripotency: the decision-making signalling pathways." Int J Dev Biol 54(11-12): 1575-1587.

Sato, N., L. Meijer, L. Skaltsounis, P. Greengard and A. H. Brivanlou (2004).

"Maintenance of pluripotency in human and mouse embryonic stem cells through activation of Wnt signaling by a pharmacological GSK-3-specific inhibitor." Nat Med 10(1): 55-63.

Shi, Y., C. Desponts, J. T. Do, H. S. Hahm, H. R. Scholer and S. Ding (2008). "Induction of pluripotent stem cells from mouse embryonic fibroblasts by Oct4 and Klf4 with small-molecule compounds." Cell Stem Cell 3(5): 568-574.

Shi, Y., J. T. Do, C. Desponts, H. S. Hahm, H. R. Scholer and S. Ding (2008). "A combined chemical and genetic approach for the generation of induced pluripotent stem cells." Cell Stem Cell 2(6): 525-528.

Silva, J., O. Barrandon, J. Nichols, J. Kawaguchi, T. W. Theunissen and A. Smith (2008). "Promotion of reprogramming to ground state pluripotency by signal inhibition." PLoS Biol 6(10): e253.

Simeone, D. M. (2008). "Pancreatic cancer stem cells: implications for the treatment of pancreatic cancer." Clin Cancer Res 14(18): 5646-5648.

Singhal, N., J. Graumann, G. Wu, M. J. Arauzo-Bravo, D. W. Han, B. Greber, L. Gentile, M. Mann and H. R. Scholer (2010). "Chromatin-Remodeling Components of the BAF Complex Facilitate Reprogramming." Cell 141(6): 943-955.

Singla, D. K., D. J. Schneider, M. M. LeWinter and B. E. Sobel (2006). "wnt3a but not wnt11 supports self-renewal of embryonic stem cells." Biochem Biophys Res Commun 345(2): 789-795. 
Smith, Z. D., I. Nachman, A. Regev and A. Meissner (2010). "Dynamic single-cell imaging of direct reprogramming reveals an early specifying event." Nat Biotechnol 28(5): 521-526.

Soufi, A., G. Donahue and K. S. Zaret (2012). "Facilitators and impediments of the pluripotency reprogramming factors' initial engagement with the genome." Cell 151(5): 994-1004.

Sridharan, R., J. Tchieu, M. J. Mason, R. Yachechko, E. Kuoy, S. Horvath, Q. Zhou and K. Plath (2009). "Role of the murine reprogramming factors in the induction of pluripotency." Cell 136(2): 364-377.

Stadtfeld, M., M. Nagaya, J. Utikal, G. Weir and K. Hochedlinger (2008). "Induced pluripotent stem cells generated without viral integration." Science 322(5903): 945-949.

Staerk, J., C. A. Lyssiotis, L. A. Medeiro, M. Bollong, R. K. Foreman, S. Zhu, M. Garcia, Q. Gao, L. C. Bouchez, L. L. Lairson, B. D. Charette, L. Supekova, J. Janes, A. Brinker, C. Y. Cho, R. Jaenisch and P. G. Schultz (2011). "Pan-Src family kinase inhibitors replace Sox 2 during the direct reprogramming of somatic cells." Angew Chem Int Ed Engl 50(25): 5734-5736.

Subramanyam, D., S. Lamouille, R. L. Judson, J. Y. Liu, N. Bucay, R. Derynck and R. Blelloch (2011). "Multiple targets of miR-302 and miR-372 promote reprogramming of human fibroblasts to induced pluripotent stem cells." Nat Biotechnol 29(5): 443-448.

Takahashi, K., K. Tanabe, M. Ohnuki, M. Narita, T. Ichisaka, K. Tomoda and S. Yamanaka (2007). "Induction of pluripotent stem cells from adult human fibroblasts by defined factors." Cell 131(5): 861-872.

Takahashi, K. and S. Yamanaka (2006). "Induction of pluripotent stem cells from mouse embryonic and adult fibroblast cultures by defined factors." Cell 126(4): 663-676.

Taylor, S. M. and P. A. Jones (1979). "Multiple new phenotypes induced in 10T1/2 and 3T3 cells treated with 5-azacytidine." Cell 17(4): 771-779.

Vallier, L., S. Mendjan, S. Brown, Z. Chng, A. Teo, L. E. Smithers, M. W. Trotter, C. H. Cho, A. Martinez, P. Rugg-Gunn, G. Brons and R. A. Pedersen (2009).

"Activin/Nodal signalling maintains pluripotency by controlling Nanog expression." Development 136(8): 1339-1349.

Varga, A. C. and J. L. Wrana (2005). "The disparate role of BMP in stem cell biology." Oncogene 24(37): 5713-5721. 
Wang, L. and Y. G. Chen (2015). "Signaling Control of Differentiation of Embryonic Stem Cells toward Mesendoderm." J Mol Biol.

Wang, P. and J. Na (2013). "Reprogramming to pluripotency and differentiation of cells with synthetic mRNA." Methods Mol Biol 969: 221-233.

Wang, Q., X. Xu, J. Li, J. Liu, H. Gu, R. Zhang, J. Chen, Y. Kuang, J. Fei, C. Jiang, P. Wang, D. Pei, S. Ding and X. Xie (2011). "Lithium, an anti-psychotic drug, greatly enhances the generation of induced pluripotent stem cells." Cell Res 21(10): 1424-1435.

Warren, L., P. D. Manos, T. Ahfeldt, Y. H. Loh, H. Li, F. Lau, W. Ebina, P. K. Mandal, Z. D. Smith, A. Meissner, G. Q. Daley, A. S. Brack, J. J. Collins, C. Cowan, T. M. Schlaeger and D. J. Rossi (2010). "Highly efficient reprogramming to pluripotency and directed differentiation of human cells with synthetic modified mRNA." Cell Stem Cell 7(5): 618-630.

Wu, Y. L., G. N. Pandian, Y. P. Ding, W. Zhang, Y. Tanaka and H. Sugiyama (2013). "Clinical grade iPS cells: need for versatile small molecules and optimal cell sources." Chem Biol 20(11): 1311-1322.

Xie, M., N. Cao and S. Ding (2014). "Small molecules for cell reprogramming and heart repair: progress and perspective." ACS Chem Biol 9(1): 34-44.

Yamanaka, S. (2012). "Induced pluripotent stem cells: past, present, and future." Cell Stem Cell 10(6): 678-684.

Yamanaka, S. and H. M. Blau (2010). "Nuclear reprogramming to a pluripotent state by three approaches." Nature 465(7299): 704-712.

Yang, C. S., Z. Li and T. M. Rana (2011). "microRNAs modulate iPS cell generation." RNA 17(8): 1451-1460.

Ying, Q. L., J. Nichols, I. Chambers and A. Smith (2003). "BMP induction of Id proteins suppresses differentiation and sustains embryonic stem cell self-renewal in collaboration with STAT3." Cell 115(3): 281-292.

You, J. S. and J. H. Han (2014). "Targeting components of epigenome by small molecules." Arch Pharm Res 37(11): 1367-1374.

Yu, J., M. A. Vodyanik, K. Smuga-Otto, J. Antosiewicz-Bourget, J. L. Frane, S. Tian, J. Nie, G. A. Jonsdottir, V. Ruotti, R. Stewart, Slukvin, II and J. A. Thomson (2007). "Induced pluripotent stem cell lines derived from human somatic cells." Science 318(5858): 1917-1920. 
Yuan, X., H. Wan, X. Zhao, S. Zhu, Q. Zhou and S. Ding (2011). "Brief report: combined chemical treatment enables Oct4-induced reprogramming from mouse embryonic fibroblasts." Stem Cells 29(3): 549-553.

Zhang, J., P. L. Yang and N. S. Gray (2009). "Targeting cancer with small molecule kinase inhibitors." Nat Rev Cancer 9(1): 28-39.

Zhang, X. and J. Hao (2015). "Development of anticancer agents targeting the Wnt/betacatenin signaling." Am J Cancer Res 5(8): 2344-2360.

Zhang, X. Z. (2010). "Modulation of embryonic stem cell fate and somatic cell reprogramming by small molecules." Reprod Biomed Online 21(1): 26-36. Zhao, T., Z. N. Zhang, Z. Rong and Y. Xu (2011). "Immunogenicity of induced pluripotent stem cells." Nature 474(7350): 212-215.

Zhou, H., S. Wu, J. Y. Joo, S. Zhu, D. W. Han, T. Lin, S. Trauger, G. Bien, S. Yao, Y. Zhu, G. Siuzdak, H. R. Scholer, L. Duan and S. Ding (2009). "Generation of induced pluripotent stem cells using recombinant proteins." Cell Stem Cell 4(5): 381-384.

Zhu, S., W. Li, H. Zhou, W. Wei, R. Ambasudhan, T. Lin, J. Kim, K. Zhang and S. Ding (2010). "Reprogramming of human primary somatic cells by OCT4 and chemical compounds." Cell Stem Cell 7(6): 651-655.

Zhu, S., W. Wei and S. Ding (2011). "Chemical strategies for stem cell biology and regenerative medicine." Annu Rev Biomed Eng 13: 73-90. 


\section{VITA}

Brittany E. Greenberg was born in 1988 to Arthur and Barbara Greenberg. She graduated Redwood High School in Larkspur, CA in 2005, and subsequently obtained her bachelor's degree in Animal Science from the University of California, Davis (UCD) in 2009. While attending UCD, Brittany was an active member in the Davis Honors Challenge for four years, and was involved in various research internships in the Department of Animal Science. After graduation, she began working as a Research Associate at the University of California, Davis Cancer Center. In 2013, she entered the Integrated Biomedical Science Program at University of Tennessee Health Science Center, Memphis, Tennessee. Shortly after, Brittany joined Dr. R. Kiplin Guy's lab at St. Jude Children's Research Hospital and studied the role of small molecule compounds in cellular reprogramming. 